\title{
The impact of easily oxidized material (EOM) on the meiobenthos: Foraminifera abnormalities in shrimp ponds of New Caledonia; implications for environment and paleoenvironment survey
}

\author{
J.-P. Debenay ${ }^{a}{ }^{*}$, L. Della Patrona ${ }^{b}$, A. Herbland ${ }^{c}$ and H. Goguenheim ${ }^{d}$ \\ a IRD, UR 055 Paléotropique, BPA5, 98848 Noumea Cedex, France \\ b IFREMER, Ifremer LEAD Lagons, Ecosystems et Aquaculture Durable, BP 2059, 98846 Nouméa Cedex - \\ Nouvelle-Calédonie, France, Luc.Della.Patrona@ifremer.fr \\ c 83 Rue des Gonthières, 17140, Lagord, France \\ d BP 7004 Taravao, 98719 TAHITI, Polynésie Française, France, Gheimiti@hotmail.com.
}

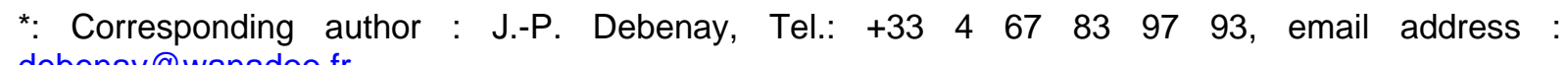
debenay@wanadoo.fr

\begin{abstract}
:
This study was carried out in shrimp ponds from New Caledonia, in order to determine the cause of the exceptional proportion of abnormal tests (FAI) (often $>50 \%$, sometimes $>80 \%$ ). FAI was positively correlated to the quantity of easily oxidized material (EOM) deposited on the bottom of the ponds and to the sediment oxygen demand, and negatively correlated to redox. These results suggest that a very high FAI is a potential indicator for great accumulations of native organic matter, leading to a high sediment oxygen demand. When studying ancient sediments in core samples, exceptional abundances of abnormal tests may indicate periods of high accumulation of EOM, and therefore of oxygen depletion. This finding should help in better management of aquaculture ponds, but should also allow new insight into the interpretation of sedimentary records, providing a useful proxy for paleoenvironmental reconstructions.
\end{abstract}

Keywords: Foraminifera; Deformations; Shrimp ponds; Organic matter; Bioindicators; SW Pacific 


\section{Introduction}

Morphological abnormalities in foraminiferal tests have long been reported and their significance discussed (e.g., Arnal, 1955; Boltovskoy, 1957; Seiglie, 1964; Boltovskoy and Wright, 1976). Abnormalities have been related to environmental stress, including salinity stress (e.g. Ayala-Castañares and Segura, 1968; Tufescu, 1968; Closs and Madeira, 1968; Zaninetti, 1982; Almogi-Labin et al., 1992), and the impact of pollution, mainly by heavy metals and organic matter, which has been considered with greater attention since the 1980's (e.g., Vénec-Peyré, 1981; Setty and Nigam, 1984; Alve, 1991; Yanko et al., 1994; Alve 1995; Yanko et al., 1998; Alve and Olsgard, 1999). Recently, an increasing number of papers are being published dealing with the impact of pollution on foraminiferal morphology (e.g., Samir and El-Din, 2001; Coccioni et al., 2003; Elberling et al., 2003; Armynot du Châtelet et al., 2004; Saraswat et al., 2004; Vilela et al., 2004; Coccioni et al., 2005; Bergin et al., 2006; Nigam et al., 2006; Le Cadre and Debenay, 2006; Burone et al., 2006; Bouchet et al., 2007; Frontalini and Coccioni, 2008; Romano et al., 2008, Nikulina et al., 2008). Some studies deal more specifically with the impact of organic matter (Caralp, 1989; Burone et al., 2006, 2007). Most of these authors consider that foraminiferal abnormalities are potentially valuable indicators of natural stress and/or pollution in present environments. They also have tentatively been used for the interpretation of past environments as far as the Cretaceous (Ballent and Carignano, 2008).

Uncertainties still exist concerning the relationship between the level of morphological abnormalities and the nature and magnitude of pollution, since the response of benthic foraminifera to stress resulting from highly changing natural environmental parameters such as salinity, temperature or $\mathrm{pH}$ superimpose onto the impact of anthropogenic pollution (Geslin et al., 2000; Debenay et al., 2001; Geslin et al., 2002; Nigam et al., 2008). Moreover, low rates of abnormalities may be found in highly polluted areas such as Santos Harbor (Brazil), whereas abnormalities are reported from low pollution areas (Geslin et al., 2002). The bioavailability of pollutants, often neglected, certainly plays a major role in test deformation (Armynot du Châtelet et al., 2003).

In laboratory cultures of Ammonia under normal conditions, $1 \%$ of tests were found to be abnormal (Stouff et al., 1999b). This proportion was considered as normal in unspoiled environments (Alve, 1991), while highly variable values have been reported as resulting from environmental stress: e.g., 2-3\% (Yanko et al., 1994); 3.5\% (Yanko et al., 1998); 5\% (Seiglie, 1975); up to 7\% (Alve, 1991); 10-20\% (Sharifi et al., 1991); more than 10\% (Coccioni et al., 
1997); 30\% (Lidz, 1965); up to11.1\% (Samir, 2000). Romano et al. (2008) recorded up to $47.3 \%$ of abnormal tests of Miliolinella subrotunda and Elphidium advena near an industrial plant operated on the coastal area of Bagnoli (Italy). In the inner zone of Montevideo Bay, Burone et al. (2006) recorded $72.7 \%$ of abnormal hyaline specimens in sediments with high organic load and low oxygen, associated with pollution by $\mathrm{Cr}$ and $\mathrm{Pb}$.

Only a few studies have been carried out on foraminiferal assemblages specifically affected by aquaculture, mainly in the Atlantic Ocean (Schafer et al., 1995; Scott et al., 1995; Bouchet et al, 2007) and in the Red Sea (Angel et al., 2000). As far as we know, the only studies dealing partially with foraminifera in shrimp farms are those from Luan and Debenay (2005), and Debenay and Luan (2006). The high input of organic matter and the wide variety of chemical and biological products used in ponds of semi-intensive and intensive shrimp farming may leave persistent, potentially toxic residues. They are likely to have a negative impact on the environment (e.g., Gräslund and Bengtsson, 2001), including foraminifera living in shrimp ponds.

The aim of this work is to investigate the response of foraminifera in semi-intensive shrimp ponds that have different environmental characteristics, with special attention to the accumulation of EOM, including native organic matter.

Pond bottom conditions are affected to a large extent by the accumulation of organic matter, such as dead algae, shrimp faeces and feed residues. This native, reactive, organic matter associated with reduced inorganic species (such as sulfides, Fe and Mn ions) constitute the active oxygen demanding pool, which leads to high oxygen consumption and the development of reducing conditions (Boyd, 1995; Avnimelech and Ritvo, 2003). The conventional method used for determination of organic matter in fresh sediments is based on a very aggressive oxidation (Walkley and Black, 1934). By this method, both fresh reactive organic matter, such as recently settled algae or feed residues, and very stable humic compounds accumulated in the soil are included in the measured value. The inability to differentiate between the two types of organic substrates and the commonly relative high background of stable organic matter make it difficult to characterize changes in the reactive fraction. Moreover, during the preparation for this conventional procedure, the samples are exposed to the air, heated and dried, which leads to the loss of very active inorganic reducing components and some organic compounds (e.g. low molecular volatile organic acids). In short, the conventional method measures quite correctly a large background, but partly ignores an unknown and probably important pertinent signal. This is why Avnimelech et al. 
(2004) proposed a method to enable determination of the redox capacity in fresh sediment samples using a relatively mild oxidation procedure with minimal treatment and exposure to the atmosphere, which allow the measure of the EOM.

\section{Study area}

Semi-intensive shrimp farming is widely distributed along the west coast of New Caledonia Main Island (Grande Terre). In New Caledonia, chemicals such as Copper compounds (elimination of external protozoans and filamentous bacterial diseases in postlarval shrimps), formalin (antifungal agent and control of ectoparasites), or antibiotics are not used, contrary to what is generally done in most of South-East Asian shrimp farms (review in Gräslund and Bengtsson, 2001). After shrimp harvest, the ponds are treated by drying for several weeks, and turning subsoil by tilling to enhance oxidation of organic matter and other reduced substances. The growing cycle lasts about four months.

Samples were collected from three shrimp farms with different characteristics (Fig. 1, 2). Two stations were selected in a pond of Saint Vincent shrimp farm (SV): Station SVA was located on a clean bottom whereas station SVB was located in an area of moderate accumulation of organic matter, where the soil never completely dried (permanent seepage). Two other stations were selected in a pond of SeaFarm shrimp farm (SF): one in an area with a high organic matter accumulation due to rotating currents induced by the paddle wheel aerator (station SF1), the second one outside of this area (station SF2). Six ponds were selected in Aigue-Marine shrimp farm (AM): two on sedimentary bottoms (stations ST1 and ST2), one on schist rocks without any sedimentary deposits, which impede to properly turn subsoil by tilling (station S2), one on a bottom made of schist fragments mixed with silt and clays (station S1), and two on bottoms fertilized by a layer of vegetable soil added before filling the ponds with marine water (stations TV1 and TV2). Seepage prevents ponds ST1 and ST2 to dry completely and organic matter and other reduced substances cannot be entirely oxidized. Due to easy access to the sea, a high water exchange system is used where water supplies consist of open-sea water, keeping salinity between 32 and $39 \%$. Water renewal varies from $0 \%$ to $30 \%$ per day, depending on shrimp biomass, and progressively increases with time. Post larvae are introduced about two weeks after the ponds were filled at a density of 18-20 individuals per square meter. Artificial feeding (pelleted food), which comprises $0.025 \%$ of mineral premix ( $\mathrm{Zn}$ sulfate, $\mathrm{Mn}$ sulfate, $\mathrm{Cu}$ sulfate) is provided in all the ponds. Feeding rates range from about $6 \mathrm{~kg}$ per ha per day at the time of introduction of post larvae 
to about $60 \mathrm{~kg}$ per ha per day before shrimp harvest.

\section{Material and methods}

The study was carried out during two successive hot seasons. Sediment samples were collected weekly at each station during a whole growing cycle, giving a total number of 170 samples. Sampling began just after the filling of the ponds and stopped after shrimp harvest. The first sampling occurred in February 2006 at stations SV and SF, and in December 2006 at the other stations. At each station, a sediment core was hand collected by means of a pvc tube, $25 \mathrm{~cm}$ in diameter and $5 \mathrm{~cm}$ long. Immediately, fifty redox measurements were carried out in the sediment with a micro redox electrode ( $\mathrm{pH} / \mathrm{mv}$ meter WTW 315i). The sediment sample for foraminiferal analysis was collected in the upper $2 \mathrm{~cm}$ of this core: About $40 \mathrm{~cm}^{3}$ of sediment were collected, and immediately frozen for preservation.

At the time of sampling, the following parameters were measured in the water column, $10 \mathrm{~cm}$ above the bottom: temperature; salinity; dissolved oxygen; ammonium. In the sediment, the measured parameters were: redox; $\mathrm{pH}$; Easily Oxidized Material (EOM); sediment oxygen demand at $25^{\circ} \mathrm{C}$, over a period of five days in the dark (SOD5, measured using BODmeter WTW Oxytop apparatus); total organic matter (OM, measured by loss on ignition weekly at stations SV and SF, and only once at the other stations); chlorophyll a and phaeopigment concentrations (flurometric analysis after extraction by methanol); abundance of bacteria. Samples for bacterial counting (about $20 \mathrm{~cm}^{3}$ ) were immediately fixed with buffered formaldehyde for bacteria ( $2 \%$ final concentration) and stored at $4{ }^{\circ} \mathrm{C}$ until bacterial counting was carried out. For counting, sediment sub-samples were sonified three times (Bioblock vibro cell 75185; $60 \mathrm{~W}$ for $1 \mathrm{~min}$ ) and diluted to $1 / 2000$ with sterile and $0.2 \_\mathrm{m}$ pre-filtered formaldehyde (2\% final concentration). Sub-samples were then stained for $30 \mathrm{~min}$ with DAPI (4',6-diamidino-2-phenylindole dihydrochloride, $2500 \mu \mathrm{g}$ DAPI $1^{-1}$ final concentration) and filtered on black Nuclepore polycarbonate (pore size $0.2 \_\mathrm{m}$ ) filters. The filters were analyzed as described by Fry (1990) and Epstein and Rossel (1995) using epifluorescence microscopy (Leica DLMN _ 1000). For each slide, at least 10 microscope fields were observed and a total of at least 300 cells were counted. Bacterial abundance was normalised to dry weight after desiccation $\left(60^{\circ} \mathrm{C}, 24 \mathrm{~h}\right)$. Heavy metals were measured in 2007 at stations SF, S, ST and TV. The EOM analyses were carried out using the procedure adapted by Della Patrona et al. (2007) from Avnimelech et al. (2004). Samples were also 
collected at the water/sediment interface for sulfide analyses: The flocculent layer was sucked up through micro pipes and stocked in flasks purged with nitrogen.

To allow comparison between the weekly-collected samples, it was necessary to collect them in the same area, but not exactly at the same place to avoid the disturbance resulting from the preceding sampling. This constraint, together with the necessity of collecting sediment samples for chemical and bacteria analyses made it impossible to collect replicates, or to use the pseudoreplication procedure (Hurlbert, 1984) adapted for foraminiferal studies (Debenay and Guillou, 2002). Consequently, the results are somewhat biased due to the microdistribution of foraminifera, but nevertheless provide informative results about the general trends affecting foraminiferal assemblages. Moreover, these results are well adapted for the interpretation of fossil assemblages collected in sedimentary cores, where sample sizes are small, representing a limited surface.

At the laboratory, samples were defrosted, and wet samples were sieved through $500 \mu \mathrm{m}$ and $63 \mu \mathrm{m}$ sieves. The $63-500 \mu \mathrm{m}$ fraction was stained with Rose Bengal to help recognize living individuals at the time of sampling (Walton, 1952; Murray and Bowser, 2000). Observations were made on dry sediment after concentrating the tests by flotation, using perchloroethylene $\left(1.622 \mathrm{~g} \mathrm{~cm}^{-3}\right)$. The unfloated sediment of the core samples was checked for the detection of remaining tests, but only a few tests were left in the sediment. When numerous enough, one to two hundred specimens (Fatela and Taborda, 2002) were identified and counted under a binocular microscope (ZEISS- Stemi 2000C), following the generic classification of Loeblich and Tappan (1987). The count results were normalized to $50 \mathrm{~cm}^{3}$ of sediment. Living and abnormal specimens were counted separately and their proportions were calculated for each sample. Comparison between the proportion of abnormality in living specimens and in total (living+dead) assemblages showed that the trends are the same, with smoothed variations, in the case of total assemblages (fig. 3). As a consequence, we decided to use total assemblages, which provide more information for samples with a low living specimen content.

Average values of the environmental parameters at each station were used for a correlation analysis with the average values of the proportion of abnormal specimens (named Foraminiferal Abnormality Index [FAI] by Coccioni et al., 2003, 2005). The two stations ST2 and S2 with respectively a highly variable FAI and a general increase of FAI with time were selected for a more detailed comparison between FAI, SOD5, EOM, redox and bacteria abundance. 


\section{Results}

\subsection{Physico chemical characteristics}

Temperature averaged $26{ }^{\circ} \mathrm{C}$ at all stations (Table 1). The AM ponds were slightly hypersaline, with salinity ranging between 38 and $39 \%$. Pond SF was normal marine (34.84\%o) and pond SV slightly hyposaline $(32.83 \%$ ). The sediment $\mathrm{pH}$ was lower than 7.5 only in ponds ST and TV, but even in these stations, it was higher than 8 in the overlying water. Higher concentrations of chlorophyll and ammonium $\left(\mathrm{NH}_{4}\right)$ in the water, and EOM in the sediment were found in SF and SV ponds. As expected, the highest values were found in areas previously identified as subjected to organic matter accumulation (SF1 and SVB). These stations did not have the highest number of bacteria, which was found at station SF2. They had the lowest average redox values, and the highest sulfide content and SOD5, but also had high oxygen contents in the overlying water. Concentrations of heavy metals in bottom sediments ranged from 22 to $46 \mathrm{ppm}$ for $\mathrm{Cu} ; 85$ to $99 \mathrm{ppm}$ for $\mathrm{Zn}$, except one value of 344 in a ST pond; and 400 to $600 \mathrm{ppm}$ for Ni. During the growing cycle, the main trends in all the ponds were an increase of EOM and of SOD5, and a decrease of redox whilst the $\mathrm{pH}$ first increased, before decreasing at the end of the cycle (fig. 4). The organic matter content (OM) ranged between 3.56 and $7.30 \%$, depending on the ponds, without significant increase during the growing cycle in ponds SV and SF where weekly measures were carried out.

\subsection{Foraminiferal assemblages}

The number of species found in any sample was less than 8, except in SV shrimp farm, where it reached a maximum of 15 . The cumulative number of species found throughout the shrimp farms was 51 (Appendix 1). The number of individuals normalized to $50 \mathrm{~cm}^{3}$ of sediment ranged from 0 , at the beginning of the growing cycle in a pond supplied with vegetable soil, to 50,000 (Table 2). Two taxa were highly dominant: Ammonia tepida and

Quinqueloculina cf. seminulum. Several species are certainly grouped under this last name since frequent and strong abnormalities make it impossible to distinguish the typical characteristics of the species (Plate 1); specimens here referred to as $Q$. seminulum may include other morphologically similar species. These two taxa made up 65 to $100 \%$ of the assemblages (except $50 \%$ in a sample with only 30 individuals). 
Almost all the species providing more than ten individuals in the whole sampling area had abnormal specimens (Plate 1). The FAI reached values higher than what has ever been reported in the literature, with more than $80 \%$ of abnormal tests in several samples (Table 2). Ammonia tepida frequently shows siamese twins. Differences exist among the ponds, the less affected (ST1) having an average of about 30\% abnormal specimens whilst the average is about $60 \%$ in the most affected pond (SF 1) (fig. 5). Clear differences in FAI values were found between the stations of Sea Farm and Saint Vincent. FAI was mostly higher than 50\% at the "dirty" stations (SF1 and SVB) and mostly lower than 50\% at the "clean" stations (SF2 and SVA). These differences were less obvious between Aigue Marine ponds where average values of EOM and SOD5 were lower, and where Redox was higher (fig. 5).

At all stations, the proportion of abnormal specimens was highly variable in time (fig. 5). Part of this variability may result from the difficulty in detecting small deformations, but general trends clearly appeared at most of the stations. The trends were reverse at the two stations SVA and SVB. At station SVA ("clean"), the FAI was lower than 50\% in most of the stations. After a slight increase in March and April, it decreased in May before a last increase in June. At station SVB ("dirty"), the FAI was higher than $50 \%$ in most of the stations. It decreased in March, increased in April and May and decreased in June. In the same way, strong differences occurred between stations SF1 and SF2: The FAI was higher than $50 \%$ at SF1 ("dirty") and mostly lower at SF2 (“clean"). Changes with time were quite irregular, but a slight general decrease trend occurred at station SF1, while FAI slightly increased at station SF2. Ponds TV1 and TV2 showed very irregular values of FAI, but these values were generally calculated on a small number of tests, mainly during the first weeks, and are not really significant. In the other ponds, the most obvious changes were found in ST2 pond. The FAI was higher at the beginning of the culture cycle, decreased at the end of December and beginning of January, increased in January, decreased again at the beginning of February before increasing at the end of this month, with an ultimate decrease in March. Roughly similar trends could be seen at stations ST1, S1 and S2, even if the intensity of change may be somewhat different, and periods of changes somewhat shifted. Superimposing upon these trends, a general increase could be seen at station S2. In all the ponds, the porcelaneous tests became thinner and almost transparent at the end of the growing cycle, but no decalcification has been observed.

At station ST2, the FAI increased with time and peaked three times, around December 15th, January 20th and first of March (fig. 6). Peaks occur at the same time in living and total assemblages, which may result from the high percentage of living specimens that is probably 
higher than measured due to the uncertainty of Rose Bengal staining. The two first peaks are related to high values of the number of bacteria and SOD5, the second one being also related to a sharp redox decrease. The last peak is related to a peak value of the number of bacteria and a rapid decrease of redox. The EOM follows the same general trend of increasing values, but the peak values do not correlate with the other parameters. At station S2, the FAI, the number of bacteria, SOD5 and EOM show a similar and very irregular increasing trend. The position of the peak values and redox decreases are also correlated (fig. 7).

The regressions between EOM and redox were high at both stations: $\mathrm{R}^{2}=0.656$ at station $\mathrm{S} 2$ and $\mathrm{R}^{2}=0.650$ at station ST2 (fig. 8). The regressions between EOM and SOD5 were $\mathrm{R}^{2}=0.589$ at station S2 and only 0.347 at station ST2 (fig. 9). At station S2, correlation between bacteria and $E O M$ was strong $\mathrm{R}^{2}=0.635$, while only a weak correlation was found between FAI and EOM $\left(\mathrm{R}^{2}=0.122\right)$ and FAI and redox $\left(\mathrm{R}^{2}=0.119\right)$, and no correlation between FAI and SOD5 $\left(\mathrm{R}^{2}=0.047\right)$. At station ST2, most of the correlations were weaker: $\mathrm{R}^{2}=0.293$ between bacteria and EOM; $\mathrm{R}^{2}=0.245$ between FAI and EOM; $\mathrm{R}^{2}=0.085$ between FAI and redox; $\mathrm{R}^{2}=0.026$ between FAI and SOD5 (fig. 10).

Contrary to what was observed with time-series data, correlations were found between the average values of FAI at each station over the period of study and average physico-chemical parameters. The correlation analysis showed strong positive correlations of FAI with SOD5 and EOM, and a strong negative correlation with redox (Table 3). The other parameters, and particularly salinity and $\mathrm{pH}$, often reported to be responsible of test deformations, are not correlated with FAI.

\section{Discussion}

Time-related changes in the physico-chemical characteristics of the shrimp farm sediment are consistent with the results reported in the literature. As reported by Boyd (1995), redox values decreased with time whilst the total organic matter did not show any significant increase along the growing cycle. Thus, it was impossible to determine the addition of newly produced organic matter due to the culture, as mentioned by Avnimelech et al. (2004). The input of this native organic matter may be indicated by the measure of EOM (Avnimelech et al., 2004).

The very small number of foraminiferal species found in the shrimp ponds indicates very restricted conditions. As the dominant species Ammonia tepida and Quinqueloculina seminulum are resistant species (review in Debenay et al., 2000; Debenay and Guillou, 2002), 
their dominance in all the shrimp ponds is the sign of strong environmental perturbations, which is corroborated by the very high proportion of abnormal specimens that reach values that never have been reported in the literature. Only Burone et al. (2006) reported almost as high values in samples from Montevideo Bay. The rapid changes in the proportion of abnormal tests with time shows that foraminifera react very quickly to changes in environment conditions.

The different modes of abnormality in test morphology already reported in the literature have been recognized: reduced size of one or more chambers, aberrant chamber shape, distorted chamber arrangement or change in coiling, abnormal additional chambers, abnormally protruding chambers or proloculus, and siamese twins (Alve, 1991; Sharifi et al., 1991; Almogi-Labin et al., 1992; Yanko et al., 1994, 1998; Stouff et al., 1999a; Geslin et al., 2002).

Following Boltovskoy et al. (1991) and Alve (1995) abnormalities may result from multiple effects, and it is very difficult to isolate any single specific cause. A comprehensive synthesis about foraminiferal abnormalities and their causes has been achieved by Geslin et al. (2002). Some authors have noted the effect of salinity variations and hypersaline conditions on the occurrence of abnormal tests (e.g., Ayala-Castañares and Segura, 1968; Resig, 1974; Cann and Deckker, 1981; Zaninetti, 1982; Almogi-Labin et al., 1992; Geslin et al., 2002). Ammonia tepida often has abnormal tests in abnormal saline conditions, although it is known to be tolerant to salinity changes and hypersalinity (e.g. Stouff et al., 1999b). Almogi-Labin et al. (1992) reported up to $57 \%$ of abnormal tests in a hypersaline pool. The great number of siamese twins of Ammonia tepida seems consistent with a salinity impact because abnormal salinity may reduce the dispersion of the juveniles, resulting in their fusion and the formation of double and multiple tests with complex abnormal forms (Stouff et al., 1999a). However, the renewal of pond water by pumping sea water leads to almost constant salinity, close to normal marine conditions, and no significant differences could be noted between the slightly hypersaline AM ponds, the normal marine SF pond and the slightly hyposaline SV pond. Therefore, abnormal tests from the shrimp ponds cannot be related to salinity stress. Abnormalities in foraminiferal tests may also result from test damages caused by hydrodynamics (Vilela and Koutsoukos, 1992; Geslin et al., 1998, 2002) or predators (Aktürk, 1976). In this case, the tests show regeneration on their broken parts. Such regenerations were not seen in the shrimp farms, where hydrodynamics is quite weak. Shrimps (Litopenaeus stylirostris) eat foraminifera (Della Patrona, unpublished data), but do not seem to break tests during predation. 
Another important parameter reported to induce test abnormality is the $\mathrm{pH}$. When $\mathrm{pH}$ values are lower than 7.5, decalcification of the test begins and may lead to complete decalcification (Le Cadre et al., 2003). When decalcified living specimens are again subjected to favorable conditions, they are able to recalcify their chambers. This process often leads to morphological abnormalities (Stouff, 1998; Stouff et al., 1999b; Le Cadre et al., 2003). Moreover, acidic conditions lead to a reduction or an absence of pseudopodial emissions in Ammonia beccarii (Travis and Bowser, 1991; Stouff et al., 1999a); this pattern may contribute to the formation of siamese twins. However, the average value of $\mathrm{pH}$ was lower than 7.5 only in shrimp ponds ST and TV (Table 1) that did not exhibit more abnormal specimens than other stations. Even if porcelaneous tests became thinner and transparent at the end of the growing cycle, when the $\mathrm{pH}$ decreases, no decalcification of foraminiferal tests has been observed. The lowest sediment $\mathrm{pH}$ recorded at station ST and TV did not seem to produce decalcification, probably because of the high $\mathrm{pH}$ of the overlying water $(>8)$ that protects the foraminifera living at or near the interface water-sediment. Thus, $\mathrm{pH}$ cannot be considered as responsible for the exceptionally high rate of test abnormalities recorded in the pond.

Several authors (Naidu et al., 1985; Sharifi et al., 1991; Yanko et al., 1994 and 1998; Schafer, 2000; Saraswat et al., 2004; Le Cadre and Debenay, 2006) interpreted the presence of morphological abnormalities as a response to the presence of heavy metal pollution. However, the correlations between heavy metals and test abnormalities are sometimes contradictory, which probably result from the non-consideration of whether heavy metals are bioavailable or not. These uncertainties in the response of foraminifera to heavy metal pollution led de Nooijer et al. (2007) to assert that relative abundances of abnormal tests in fossil samples are not suitable to reconstruct past copper concentrations. New Caledonian shrimp ponds were built far from any anthropogenic pollution, and are exempt of copper compounds treatments. The input of metals with pelleted food $\left(\mathrm{ZnSO}_{4}, \mathrm{MnSO}_{4}, \mathrm{CuSO}_{4}\right)$ ranges from $1.5 \mathrm{~g} \mathrm{ha}^{-1} \mathrm{~d}^{-1}$, when the ponds are stocked with post larvae, to $14 \mathrm{~g} \mathrm{ha}^{-1} \mathrm{~d}^{-1}$ just before shrimp harvest. A great part of these metals, provided in the form of soluble sulfates, are probably drained off to the sea during water renewal, or accumulate in shrimp tissues, a very low amount being deposited. The concentrations of heavy metals measured in 2007, compared with the reference values of international regulatory bodies (US EPA, 1993), indicate that, except for one value, $\mathrm{Zn}$ concentrations are inside the range for non polluted $(<90 \mathrm{ppm})$ to moderately polluted sediments $(90-200 \mathrm{ppm})$, and Ni concentrations are inside the range for highly polluted environments $(>50 \mathrm{ppm}) . \mathrm{Cu}$ concentrations correspond to moderately polluted sediments (20-50 ppm), but only a low proportion of abnormal tests were 
previously reported in such concentrations of $\mathrm{Cu}$ (e.g., Sharifi et al., 1991; Yanko et al., 1998; Gonzalez-Regalado et al., 2001). Consequently, in the present conditions only Ni seems likely to produce test abnormalities. However, due to mining activities, pollution by $\mathrm{Ni}$ is a usual feature along the New Caledonian coasts, and observations carried out in a bay affected by direct terrigenous inputs from mining areas ( $\mathrm{Ni}$ concentrations frequently higher than $1000 \mathrm{ppm}$ ) did not show increased numbers of abnormal tests (Debenay, unpublished data). We can thus infer that heavy metals cannot be responsible for the very high proportion of abnormal tests in the shrimp ponds.

In polluted environments, organic matter generally accumulates together with heavy metals and studies dealing with test abnormalities give the pre-eminence to heavy metals. Organic matter is rarely considered alone to be responsible for test abnormalities. However, the presence of up to $25 \%$ of abnormal tests of Melonis barleeanun at a level corresponding to the Last Glacial Maximum, in a core from Mauritania, was interpreted as the result of an abundant supply of little-altered OM (Caralp, 1989). In Ubatuba Bay (Brazil), which is affected by increasing amounts of organic pollutants caused by the fast growth of tourism, Burone et al. (2007) found a high density of abnormal tests of Ammonia tepida. In the inner zone of Montevideo Bay, the proportion of hyaline specimens with morphological abnormalities reached $72.7 \%$ (Burone et al., 2006). These last authors related these very high proportions to high organic load and low oxygen content in bottom sediments, associated with pollution by $\mathrm{Cr}$ and $\mathrm{Pb}$. The very high proportion of abnormalities associated with organic load is consistent with our findings in the shrimp ponds. The strong positive correlation of the FAI with averaged SOD5 and EOM, and the negative correlation with redox clearly indicates the role of accumulation of high oxygen demanding material. The weak correlation of FAI with sulfide, compared to the high correlation with SOD5, indicates that the contribution of sulfide to test abnormalities is weak compared to the other constituents of the active oxygen demanding pool. Consequently, reactive organic matter such as dead algae, shrimp faeces and feed residues are likely to be responsible for test abnormalities, and it is possible to infer that high proportions of test abnormalities may be considered as indicator of high native organic matter input. This finding will not only help in a better management of aquaculture ponds, but also provides new insight into the interpretation of paleoenvironment records. Indeed, on the basis of the conclusion that an abundant supply of native OM may lead to high FAI, FAI may be considered as an indicator of climatic activation of OM production in past environments. 
Alve (1991) reported test abnormalities in a zone of high stress due to oxygen depletion in the Sorfjord (Norway), with FAI lower than 7\%. These values are far lower than our records, showing that low redox values are not directly responsible for high FAI. Very high FAI are more likely related to the redox capacity, and therefore to EOM accumulations.

The significant linear correlation in time-series analyses from station S2 between SOD5 and EOM $\left(\mathrm{R}^{2}=0.589\right)$ is consistent with the value of 0.622 reported by Avnimelech et al. (2004). It shows the strong relationship between the accumulation of native organic matter and the oxygen demand of the sediment, which is corroborated by the strong negative correlation between EOM and redox. The impact of native organic matter on bacteria development is shown by the significant correlation between bacteria and EOM $\left(\mathrm{R}^{2}=0.635\right)$. The weak correlation between FAI and EOM and the absence of correlation between FAI and SOD5 may be explained by heterochronies in the formation of abnormalities in foraminiferal tests: Abnormalities may appear only when new chambers are added. Young individuals may build one chamber every day while adults may need several days. Consequently, the higher the amount of young specimens the quicker abnormalities appear, which cannot allow a direct correlation between changes in environmental characteristics and reactions of the entire population. Therefore, using average values provides better information than time-series analyses in such studies.

The weaker correlations between all parameters at station ST2 may be explained by the differences between the two stations. S2 had a sterile rocky bottom on which native organic matter accumulated. On the contrary, the sedimentary bottom of ST2 contained remaining organic matter and reduced substance that was not totally oxidized, owing to the seepage that prevents this pond to completely dry between two growing cycles. As seen before, despite their different changes with time, the two ponds provide results that are consistent with all the other ponds when considering the average values.

The very irregular trends of FAI at all stations can be explained by short-term events as exemplified at station ST2. Peaks in bacteria population, leading to rapid degradation of EOM, increase of SOD5, and decrease of redox may create stress conditions that generate test deformations. The occurrence of such events may be enhanced by a higher stock of EOM in the dirty ponds. The irregularity of these events together with the delay in the response of foraminifera and to the heterochronies in the formation of abnormalities, as mentioned above, may explain why it was impossible to find correlations between FAI and EOM in time-series data. Moreover, foraminiferal assemblages change with time, dominated by Ammonia tepida at the beginning of the cycle and by Quinqueloculina seminula at the end (Debenay et al. in 
press). This last species may escape adverse conditions by climbing through the organic floc that accumulates on the bottom of the pond during the growing cycle, which may explain the paradoxical decrease of FAI at the end of the study.

\section{Conclusion}

The percentage of abnormal foraminiferal tests (FAI) collected in the shrimp ponds of New Caledonia is higher than what has ever been reported from other areas subjected to pollution or environmental stress. Previous studies that also reported high rates of test abnormalities were carried out in areas of organic matter accumulation, and sometimes suggest the role of this organic matter as responsible for increased FAI. This study shows that it is the nature of organic matter rather than its quantity that acts on test abnormalities. Native organic matter, which comprises most of the EOM, and induces a high oxygen demand, appears as the most likely responsible for FAI increase. Consequently, very high rates of abnormalities may be considered as indicator of native organic matter accumulation in present environments. It could also be a very useful proxy for paleoenvironmental and paleoclimatic reconstructions.

\section{Acknowledgements}

This work was supported by IFREMER and IRD programs. The authors would like to express sincere thanks to Denis Wirrmann for his comments on an earlier version of the manuscript and his helpful suggestions. Thanks are also due to The Guest Editors Elena Romano and Luisa Bergamin and to Ruggero Matteucci and an anonymous referee who made constructive comments and suggestions that greatly improved the paper.

\section{References}

Aktürk, S.E., 1976. Traumatic variation in the Globorotalia menardii d'Orbigny group in late Quaternary sediments from the Caribbean. Journal of Foraminiferal Research 6, 186192.

Almogi-Labin, A., Perelis-Grossovicz, L., Raab, M., 1992. Living Ammonia from a hypersaline inland pool, Dead Sea area, Israel. Journal of Foraminiferal Research 22, 257-266.

Alve, E., 1991. Benthic foraminifera in sediment cores reflecting heavy metal pollution in Sorfjord, Western Norway. Journal of Foraminiferal Research 21, 1-19.

Alve, E., 1995. Benthic foraminifera response to estuarine pollution. A review. Journal of Foraminiferal Research 25, 190-203.

Alve, E., Olsgard, F., 1999. Benthic foraminiferal colonization in experiments with $\mathrm{Cu}-$ contaminated sediments. Journal of Foraminiferal Research 29, 186-195. 
Angel, D.L., Verghese, S., Lee, J.J., Saleh, A.M., Zuber, D., Lindell D., Symons, A., 2000. Impact of a net cage fish farm on the distribution of benthic foraminifera in the northern Gulf of Eilat (Aqaba, Red Sea). Journal of Foraminiferal Research 30, 54-65.

Armynot du Châtelet, E., Amiard, J-C., Debenay, J-P., Geffard, A., 2003. Métaux dans le sédiment et fraction bio disponible : influence sur les peuplements de foraminifères. $2^{\text {nd }}$ International Symposium on Contaminated Sediments, Quebec, 26-28 mai 2003. Proceedings, 311-318.

Armynot du Châtelet, E., Debenay, J-P., Soulard, R., 2004. Foraminiferal proxies for pollution monitoring in moderately polluted harbors. Environmental pollution 127, 2740.

Arnal, R.E., 1955. Significance of abnormal foraminifera. Geological Society of America Bulletin 66, 1641.

Avnimelech, Y., Ritvo, G., Kochva, M., 2004. Evaluating the active redox and organic fractions in pond bottom soils: EOM, easily oxidized material. Aquaculture 233, 283292.

Avnimelech, Y., Ritvo, G., 2003. Shrimp and fish pond soils: processes and management. Aquaculture 220, 549-567.

Ayala-Castañares, A., Segura, L.R., 1968. Ecologia y distribucion de los foraminíferos recientes de la Laguna Madre, Tamaulipas, Mexico. Universidad Nacional Autonoma de Mexico, Buletin del Instituto Geologico 87, 1-90.

Ballent, S.C., Carignano, A.P., 2008. Morphological abnormalities in Late Cretaceous and early Paleocene foraminifer tests (northern Patagonia, Argentina). Marine Micropaleontology 67, 288-296

Bergin, F., Kucuksezgin, F., Uluturhan, E., Barut, I.F., Meric, E., Avsar, N., Nazik, A., 2006. The response of benthic foraminifera and ostracoda to heavy metal pollution in Gulf of Izmir (Eastern Aegean Sea). Estuarine, Coastal and Shelf Science 66, 368-386.

Boltovskoy, E., 1957. Las anormalidades en los caparazones de foraminíferos y el 'Indice de regeneramiento'. Ameghiniana 1, 80-84.

Boltovskoy, E., Wright, R., 1976. Recent Foraminifera. Junk, W. (Ed.), The Hague.

Boltovskoy, E., Scott, D.B., Medioli, F.S., 1991. Morphological variations of benthic foraminiferal test in response to changes in ecological parameters: a review. Journal of Paleontology 65, 175-85.

Bouchet, V., Debenay, J-P., Sauriau, P-G., Radford-Knoery, J., Soletchnik, P., 2007. Effects of short-term environmental disturbances on living benthic foraminifera during the Pacific oyster summer mortality in the Marennes-Oléron Bay (France). Marine Environmental Research 64, 358-383.

Boyd, C.E., 1995. Bottom Soils, Sediments, and Pond Aquaculture. Chapman \& Hall, New York.

Burone, L., Venturini, N., Sprechmann, P., Valente, P., Muniz, P., 2006. Foraminiferal responses to polluted sediments in the Montevideo coastal zone, Uruguay. Marine Pollution Bulletin 52, 61-73.

Burone, L, Valente, P., Pires-Vanin, A., De Mello e Souza, S.H., Mahiques, M.M., Braca, E., 2007. Benthic foraminiferal variability on a monthly scale in a subtropical bay moderately affected by urban sewage. Scientia Marina 71, 775-792.

Cann, J.H., Deckker, P.D., 1981. Fossil quaternary and living foraminifera from athalassic (non-marine) saline lakes, Southern Australia. Journal of Paleontology 55, 660-670.

Caralp, M.H., 1989. Size and morphology of the benthic foraminifer Melonis barleeanum, relationships with marine oceanic matter. Journal of Foraminiferal Research 19, 235245.

Closs, D., Madeira, M.L., 1968. Seasonal variations of brackish foraminifera in the Patos 
Lagoon, southern Brazil. Universidade do Rio Grande do Sul, Escola de Geologia, Publicação especial 15, 1-51.

Coccioni, R., Gabbianelli, G., Gentiloni Silverj, D., Fonti, P., Kaminski, M.A., Monechi, S., Tateo, F., 1997. Benthic foraminiferal response to heavy metal pollution in the Goro Lagoon (Italy). In: The First International Conference on Application of Micropaleontologyin Environmental Sciences, Tel Aviv, Israel, pp. 47-48.

Coccioni, R., Marsili, A., Venturati, A., 2003. Foraminiferi e stress ambientale. Quaderni del Centro di Geobiologia dell'Università degli Studi di Urbino 1, 99-118.

Coccioni, R., Frontalini, F., Marsili, A., Troiani, F., 2005. Foraminiferi bentonici e metalli in traccia: implicazioni ambientali. Quaderni del Centro di Geobiologia dell'Università degli Studi di Urbino 3, 57-92.

de Nooijer, L.J., Reichart, G.J., Dueñas-Bohórquez, A., Wolthers, M., Ernst, S.R., Mason, P.R.D., van der Zwaan, G.J., 2007. Copper incorporation in foraminiferal calcite: results from culturing experiments, Biogeosciences 4, 493-504.

Debenay, J-P., Guillou, J-J., 2002. Ecological transitions indicated by foraminiferal assemblages in paralic environments. Estuaries 25, 1107-1120.

Debenay, J-P., Luan, B.T., 2006. Foraminiferal assemblages and the confinement index as tools for assessment of saline intrusion and human impact in the Mekong delta. Revue de Micropaléontologie 49, 74-85

Debenay, J-P., Guillou,,J-J., Redois, F., Geslin, E., 2000. Distribution trends of foraminiferal assemblages in paralic environments: a base for using foraminifera as bioindicators. In: Martin, R.E. (Ed.). Environmental Micropaleontology: The Application of Microfossils to Environmental Geology. Kluwer Academic/Plenum Publishers, New York, pp. 3967.

Debenay, J-P., Geslin, E., Eichler, B.B., Duleba, W., Sylvestre, F., Eichler, P., 2001. Foraminiferal assemblages in a hypersaline lagoon: The lagoon of Araruama (R.J.) Brazil. Journal of Foraminiferal Research 31, 133-151.

Debenay, J-P., Della Patrona, L., Goguenheim, H., in press. Colonization of coastal environments by Foraminifera: Shrimp ponds of New Caledonia. Journal of Foraminiferal Research.

Della Patrona, L., Brun, P., Herbland, A., 2007. The land of fund basins and their management during the dry phase "assec". State of knowledge (in French). Ifremer/DAC/RST. 2007-03. 52 pp. Available on the web site : http://www.ifremer.fr/docelec/doc/2007/rapport-4399.pdf

Elberling, B., Knudsen, K.L., Kristensen, P.H., Asmund, G., 2003. Applying foraminiferal stratigraphy as a biomarker for heavy metal contamination and mining impact in a fiord in west Greenland. Marine Environmental Research 55: 235-56.

Epstein, S.S., Rossel, J., 1995. Enumeration of sandy sediment bacteria: search of optimal protocol. Marine Ecology Progress Series 117, 289-298.

Fatela, F., Taborda, R., 2002. Confidence limits of species proportions in microfossil assemblages. Marine Micropaleontology 45, 169-174.

Frontalini, F., Coccioni, R., 2008. Benthic foraminifera for heavy metal pollution monitoring: A case study from the central Adriatic Sea coast of Italy. Estuarine, Coastal and Shelf Science 76, 404-417

Fry, J.C., 1990. Direct methods and biomass estimation. Methods in Microbiology 22, 41-85.

Geslin, E., Debenay, J-P., Lesourd ,M., Duleba, W., Eichler, B.B., 1998. A quantitative and qualitative study of hyaline deformed tests in a non polluted estuary (Jureia, Brazil). In: International Symposium on Foraminifera, Foram'98, Mexico, Revista de la Societad Mexicana de Paleontologia, Special Publication, p. 38.

Geslin, E., Stouff, V., Debenay, J-P., Lesourd, M., 2000. Environmental variation and 
foraminiferal test abnormalities. In: Martin, R.E. (Ed.). Environmental Micropaleontology: The Application of Microfossils to Environmental Geology. Kluwer Academic/Plenum Publishers, New York, pp. 191-215.

Geslin, E., Debenay, J-P., Duleba, W., Bonetti, C., 2002. Morphological abnormalities of foraminiferal tests in brazilian environments: comparison between impacted and non impacted areas. Marine Micropaleontology 45, 151-168.

Gonzalez-Regalado, M-L., Ruiz, F., Baceta, J-I., Gonzalez-Regalado, E., Muñoz, J-M., 2001. Total benthic foraminifera assemblages in the southwestern Spanish estuaries. Geobios 34, 39-51.

Gräslund, S., Bengtsson, B.E., 2001. Chemical and biological products used in south-east Asian shrimp farming, and their potential impact on the environment - a review. The Science of the Total Environment 280, 93-131

Hurlbertn S.J., 1984. Pseudoreplication and the design of ecological experiments. Ecological Monographs 54, 187-211.

Le Cadre, V., Debenay, J-P., 2006. Morphological and cytological response of Ammonia (Foraminifera) to copper contamination. Implication for the use of foraminifera as bioindicators of pollution. Environmental pollution 143, 304-317.

Le Cadre, V., Debenay, J-P., Lesourd, M., 2003. Low pH effects on Ammonia beccarii test deformation: implications for using test deformation as pollution indicator. Journal of Foraminiferal Research 33, 10-31.

Lidz, L., 1965. Sedimentary environment and foraminiferal parameters - Nantucket Bay, Massachussetts. Limnology and Oceanography 10, 392-402.

Loeblich, A.R., Jr., Tappan, H., 1987. Foraminiferal Genera and their Classification vol. 4. Van Nostrand Reinhold, New York.

Luan, B.T., Debenay, J-P., 2005. Foraminifera, environmental bioindicators in the highly impacted environments of the Mekong delta. Hydrobiologia 548, 75-83.

Murray, J.W., Bowser, S.S., 2000. Mortality, protoplasm decay rate, and reliability of staining techniques to recognise living foraminifera: a review. Journal of Foraminiferal Research 30, 66-70.

Naidu, T.Y., Rao, D.C., Rao, M.S., 1985. Foraminifera as pollution indicators in the Visakhapatnam Harbour Complex, east coast of India. Bulletin of Geological Mining and Metallurgical Society of India 52, 88-96.

Nigam, R., Saraswat, R., Pancharng, R., 2006. Application of foraminifers in ecotoxicology: retrospect, perspect and prospect. Environment International 32, 273-283.

Nigam, R., Kurtarkar, S.R., Saraswat, R., Linshy, V.N., Rana, S.S., 2008. Response of benthic foraminifera Rosalina leei to different temperature and salinity, under laboratory culture experiment. Journal of the Marine Biological Association of the United Kingdom 88, 699-704.

Nikulina, A., Polovodova, I., Schönfeld, J., 2008. Foraminiferal response to environmental changes in Kiel Fjord, SW Baltic Sea. eEarth, 3, 37-49. www.electronicearth.net/3/37/2008/

Resig, J.M., 1974. Recent foraminifera from a landlocked Hawaiian lake. Journal of Foraminiferal Research 4, 69-76.

Romano, E., Bergamin, L., Finoia, M.G., Carboni, M.G., Ausili, A., Gabellini, M., 2008. Industrial pollution at Bagnoli (Naples, Italy): benthic foraminifera as tool in integrated programs of environmental monitoring. Marine Pollution Bulletin 56, 439-457.

Samir, A.M., 2000. The response of benthic foraminifera and ostracods to various pollution sources: a study from two lagoons in Egypt. Journal of Foraminiferal Research 30, 8398.

Samir, A.M., El Din, A.B., 2001. Benthic foraminiferal assemblages and morphological 
abnormalities as pollution proxies in two Egyptian bays. Marine Micropaleontology 41, 193-227.

Saraswat, R., Kurtarbar, S.R., Mazumder, A., Nigam, R., 2004. Foraminifers as indicators of marine pollution: a culture experiment with Rosalina leei. Marine Pollution Bulletin 48, 91-96.

Schafer, C.T., 2000. Monitoring nearshore marine environments using benthic foraminifera: some protocols and pitfalls. Micropaleontology 46, 161-169.

Schafer, C.T., Winters, G.V., Scott, D.B., Pocklington, P., Cole, F.E., Honig, C., 1995. Survey of living foraminifera and polychaete populations at some Canadian aquaculture sites: potential for impact mapping and monitoring. Journal of Foraminiferal Research $25,236-259$.

Scott, D.B., Schafer, C.T., Honig, C., Younger, D.C., 1995. Temporal variations of benthic foraminiferal assemblages under or near aquacultutre operations: documentation of impact history. Journal of Foraminiferal Research 25, 224-235.

Seiglie, G.A., 1964. Signification de los foraminíferos anormales de la laguna de Unare. Lagena, p. 6.

Seiglie, G.A., 1975. Foraminifers of Guayanilla Bay and their use as environmental indicators. Revista Española de Micropaleontología 7, 453-487.

Setty, M.G.A.P., Nigam, R., 1984. Benthic foraminifera as pollution indices in the marine environment of west coast of India. Rivista Italiana di Paleontologia e Stratigrafia 89, 421-436.

Sharifi, A.R., Croudance, I.W., Austin, R.L., 1991. Benthic foraminiferids as pollution indicators in Southampton Water, southern England, U.K. Journal of Micropaleontology $10,109-113$.

Stouff, V., 1998. Interêt des élevages de foraminifères en laboratoire: Etudes biologiques et ultrastructurales. PhD thesis, UniversityAngers and EPHE, France, 405 p.

Stouff, V., Debenay, J-P., Lesourd, M., 1999a. Origin of double and multiple tests in benthic foraminifera: observations in laboratory cultures. Marine Micropaleontology 36, 189204.

Stouff, V., Geslin, E., Debenay, J-P., Lesourd, M., 1999b. Origin of morphological abnormalities in Ammonia (foraminifera): studies in laboratory and natural environments. Journal of Foraminiferal Research 29, 152-170.

Travis, J.L., Bowser, S.S., 1991. The mobility of foraminifera. In: Lee, J.J., Anderson, O.R. (Eds). Biology of Foraminifera. Academic Press, London, pp. 91-155.

Tufescu, M., 1968. Ammonia tepida (Cushman) (ord. Foraminifera). Some features of its variability in the Black Sea Basin. Revue Roumaine de Biologie et Zoologie 13, 169177.

US EPA, 1993. Selecting remediation techniques for contaminated sediment. EPA-823-B9315 001. U.S. Environmental Protection Agency, Office of Water.

Vénec-Peyré, M-T., 1981. Les foraminifères et la pollution: étude de la microfaune de la cale du Dourdu. (embouchure de la rivière de Morlaix). Cahiers de Biologie Marine 22, 2533.

Vilela, C., Batista, D.S., Batista-Neto, J.A., Crapeza, M., Mcallister, J.J., 2004. Benthic foraminifera distribution in high polluted sediments from Niteroi Harbor (Guanabara Bay), Rio de Janeiro, Brazil. Anais da Academia Brasileira de Ciências 76, 161-171.

Vilela, C.G., Koutsoukos, E.A.M., 1992. Miliolina (Foraminiferida) em sedimentos recentes da foz do Amazonas: uma resposta comportamental a um ambiente dinámico. In: 37th Congresso Brasileiro de Geologia - SBG/SP, São Paulo, SP, Brasil, pp. 92-93.

Walkley, A., Black, C.A., 1934. An examination of the Degtjareff method for determining soil organic matter and a proposal modification of the chromic acid titration method. 
Soil Science 37, 29-38.

Walton, W.R., 1952. Techniques for recognition of living foraminifera. Contribution from the Cushman Foundation 3, 56-60.

Yanko, V., Kronfeld, J., Flexer, A., 1994. Response of benthic foraminifera to various pollution sources: implications for pollution monitoring. Journal of Foraminiferal Research 24, 1-17.

Yanko, V., Ahmad, M., Kaminski, M.A., 1998. Morphological deformities of benthic foraminiferal tests in response to pollution by heavy metals: Implications for pollution monitoring. Journal of Foraminiferal Research 28, 177-200.

Zaninetti, L., 1982. Les Foraminifères des marais salants de Salin-de-Giraud (Sud de la France): milieu de vie et transport dans le salin, comparaison avec les microfaunes marines. Géologie Méditerranéenne 9, 447-470. 


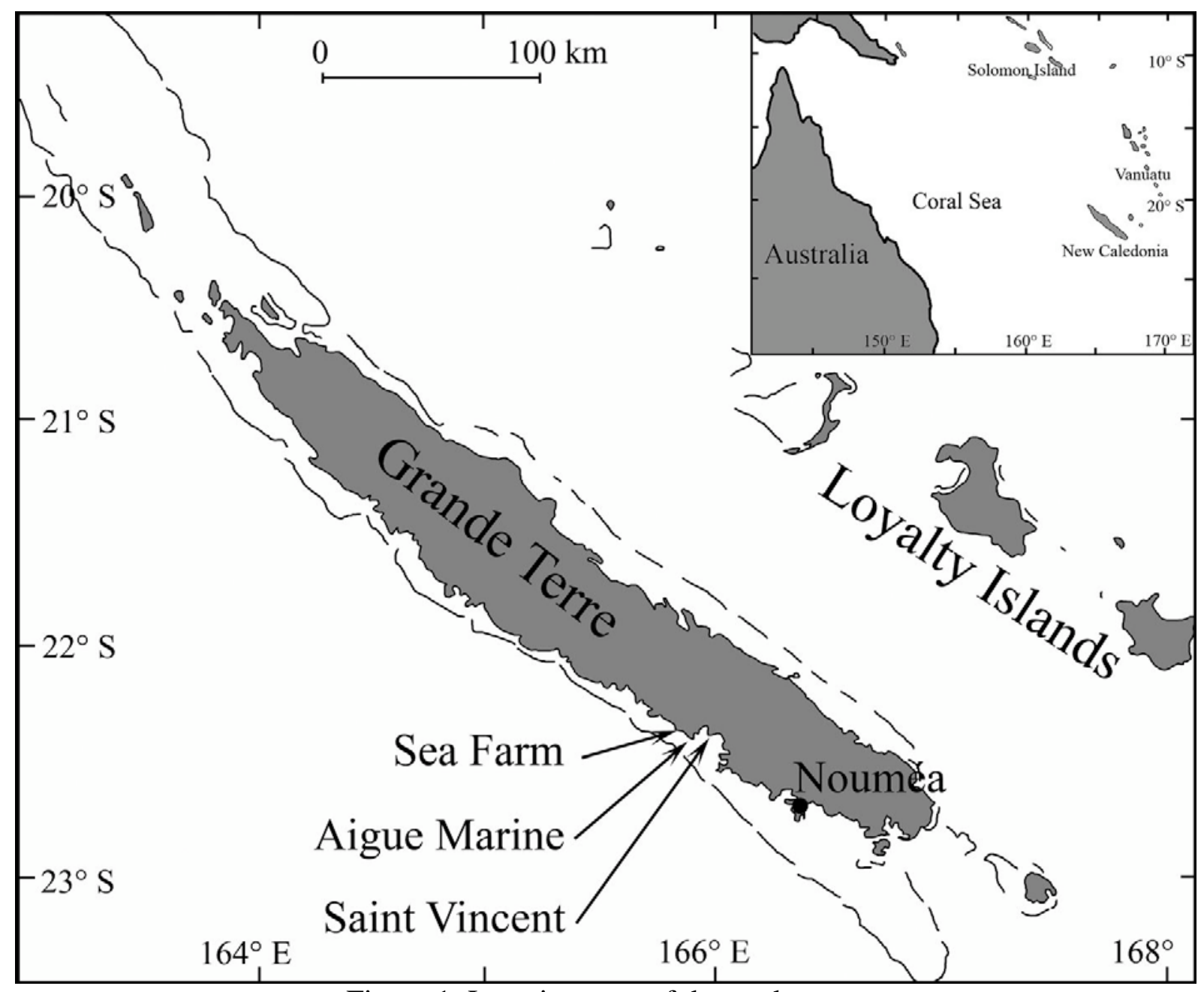

Figure 1: Location map of the study area. 


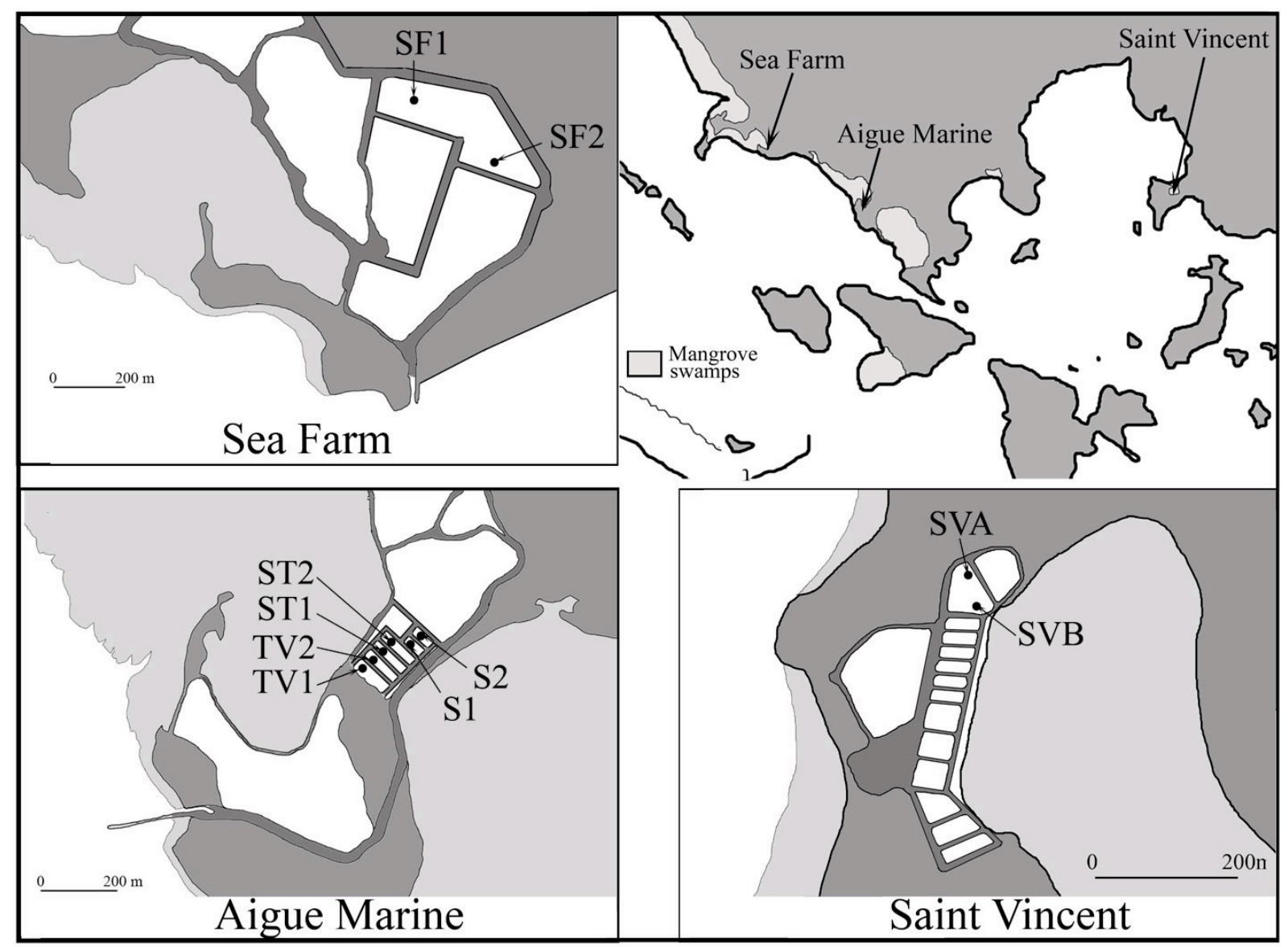

Figure 2: Locations of the sampling stations.

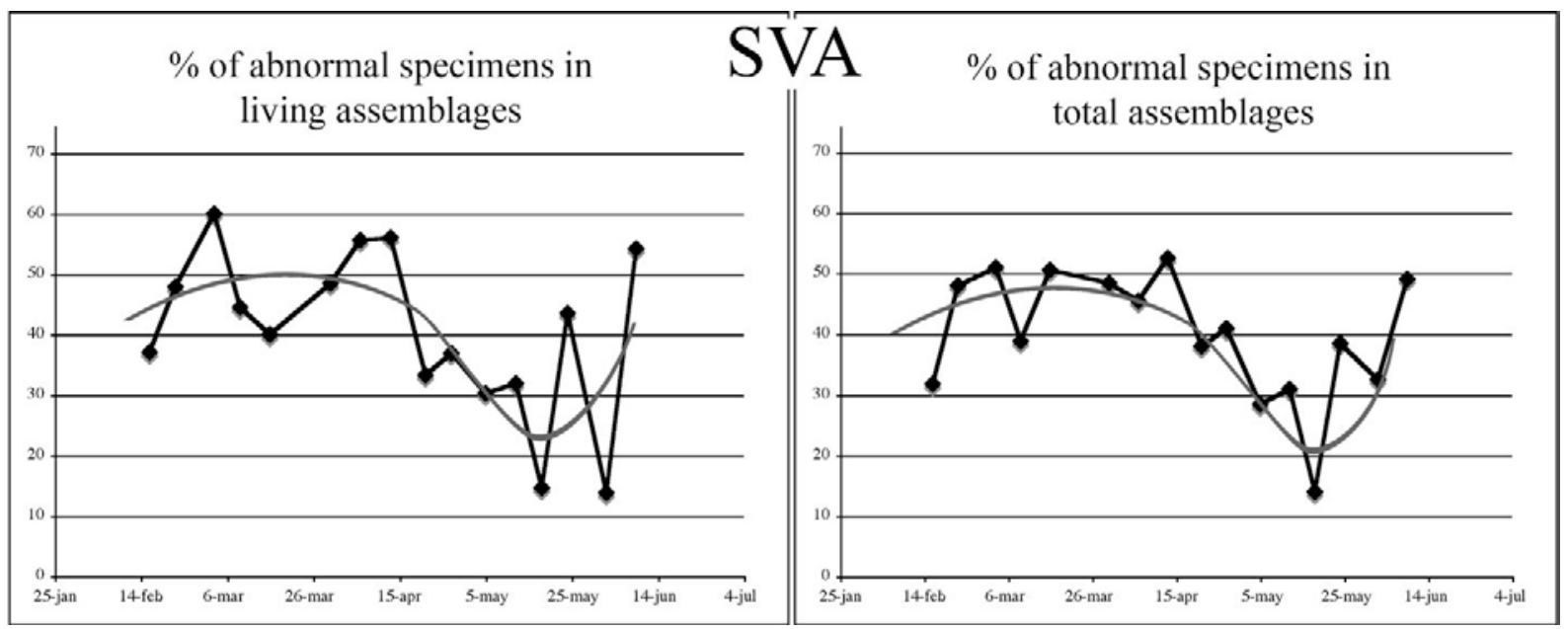

Figure 3: Comparison between the percentage of abnormal specimens in living and total assemblages at station SVA. 


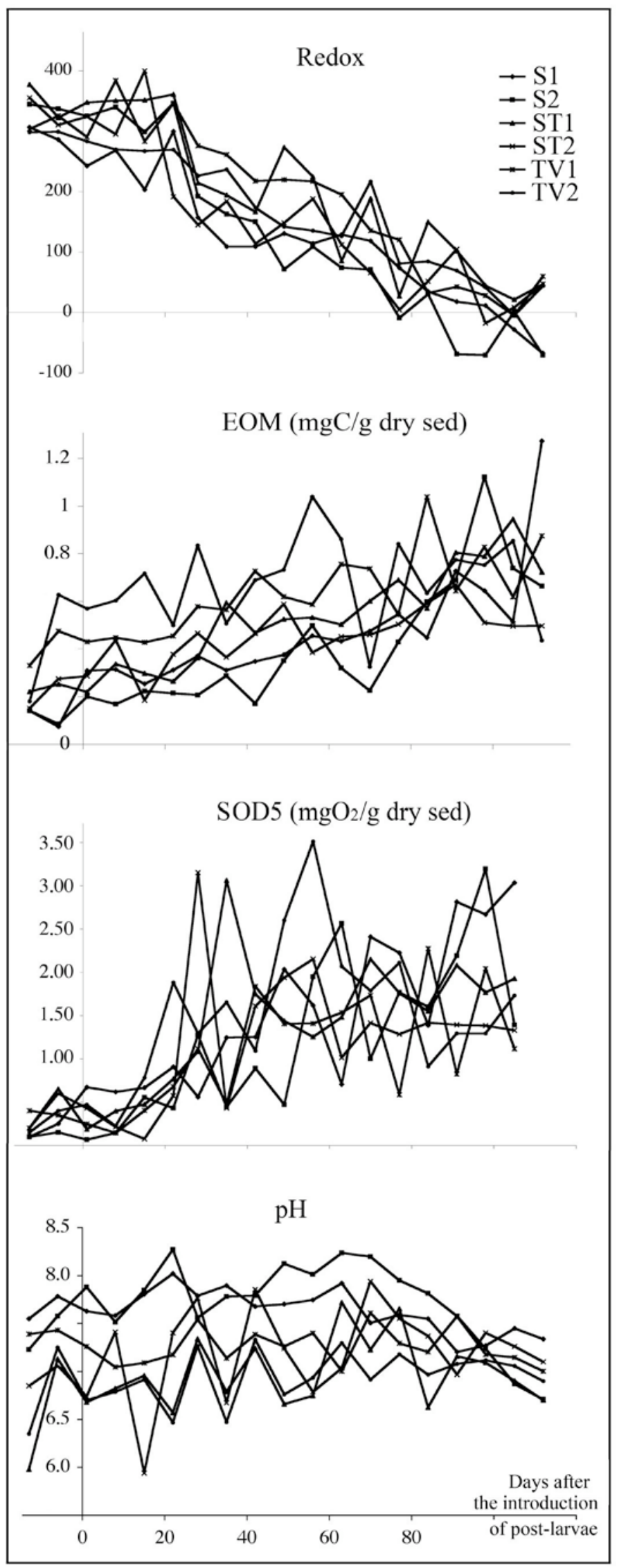

Figure 4: Changes in chemical parameters with time at stations from AM shrimp farm, showing the general trends similar in all stations. 


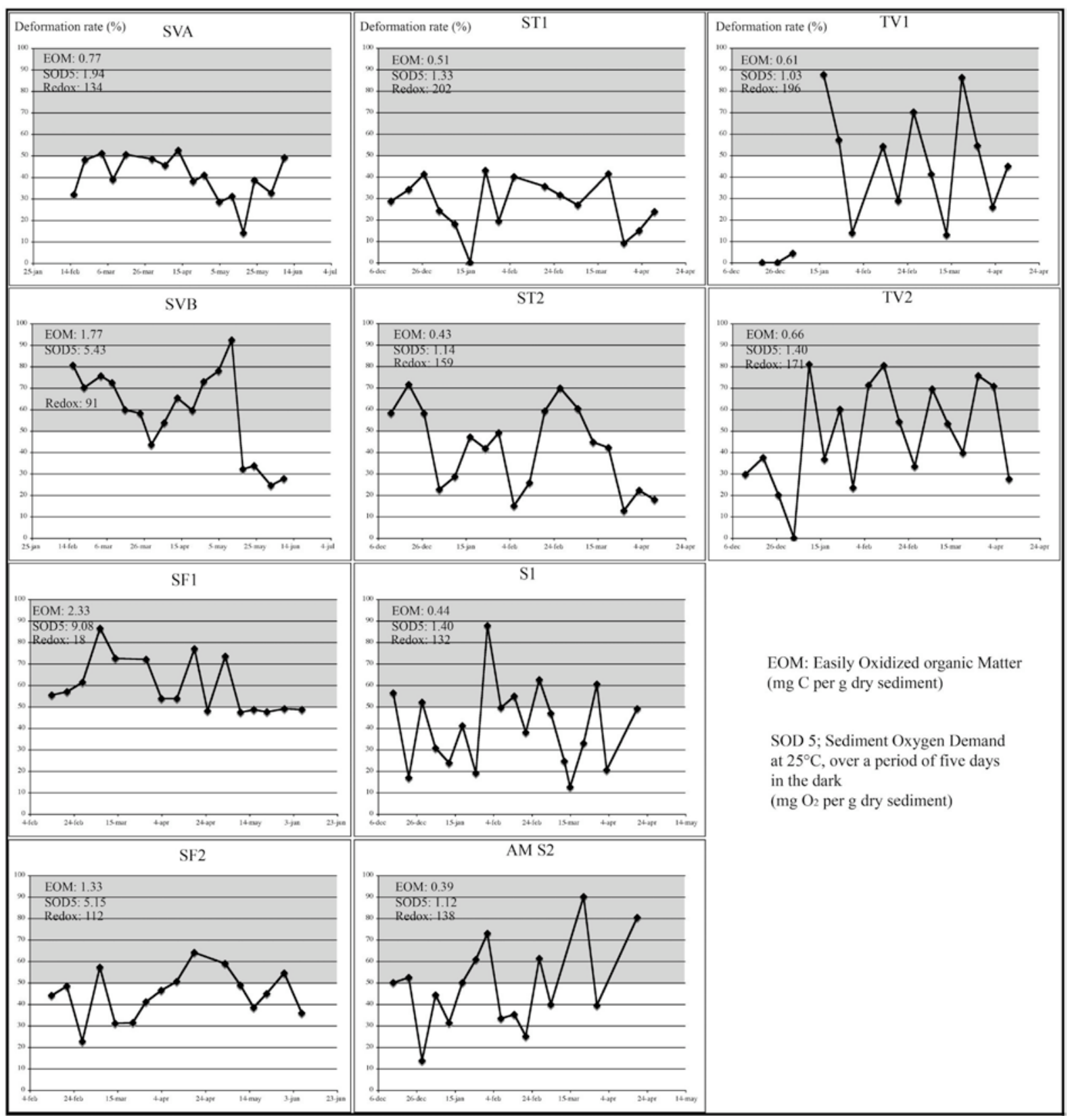

Figure 5: Changes in the percentage of abnormal specimens (FAI) with time at all stations; shadows indicate FAI $>50 \%$. Average values of EOM, SOD5 and redox are reported on the diagrams". 


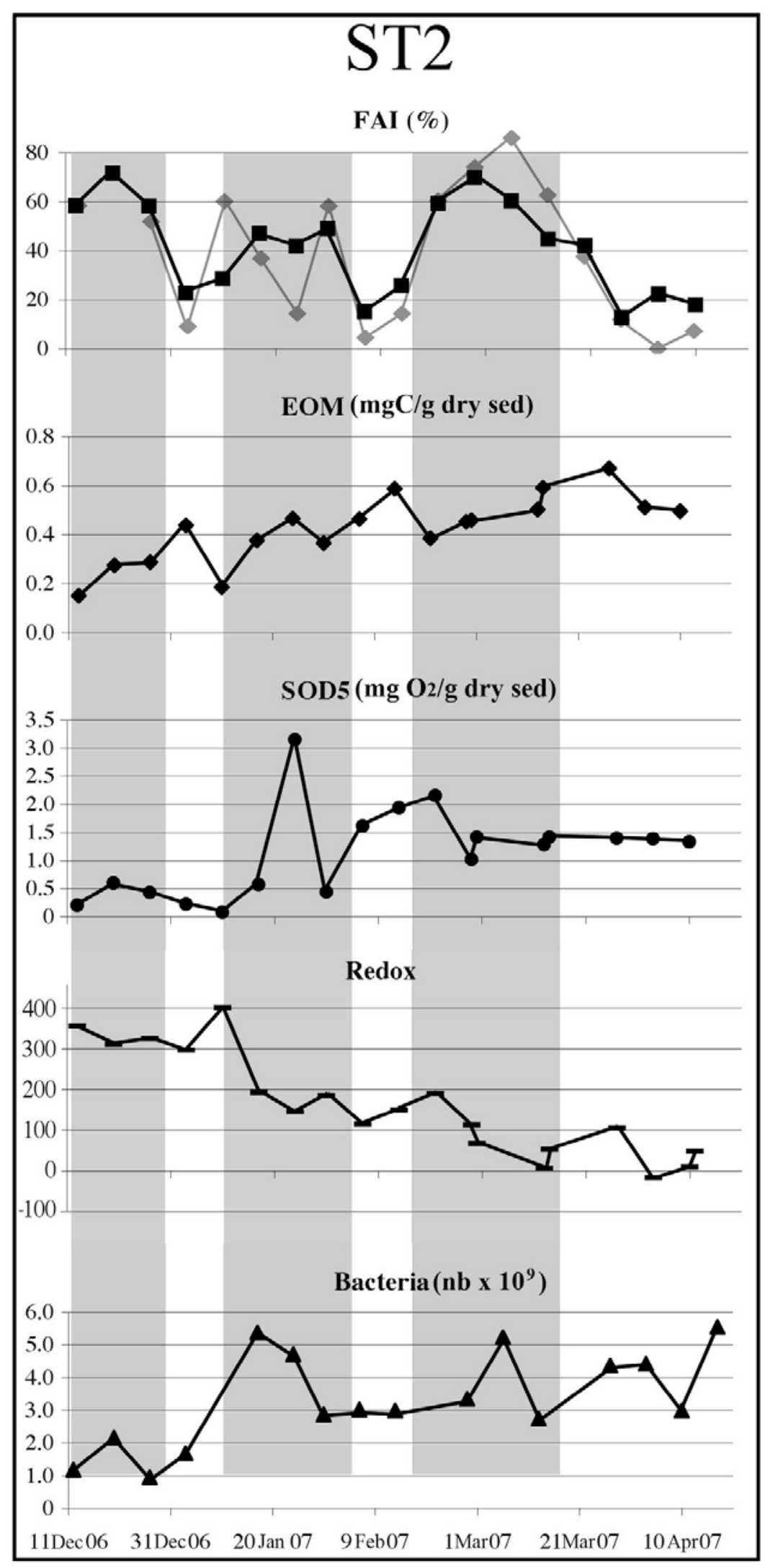

Figure 6: Changes in physico-chemical parameters and density of bacteria with time, compared with changes in FAI at station ST2; shadows indicate the main peaks of FAI values, the gray curve is for living assemblages and the black one for total assemblages. 


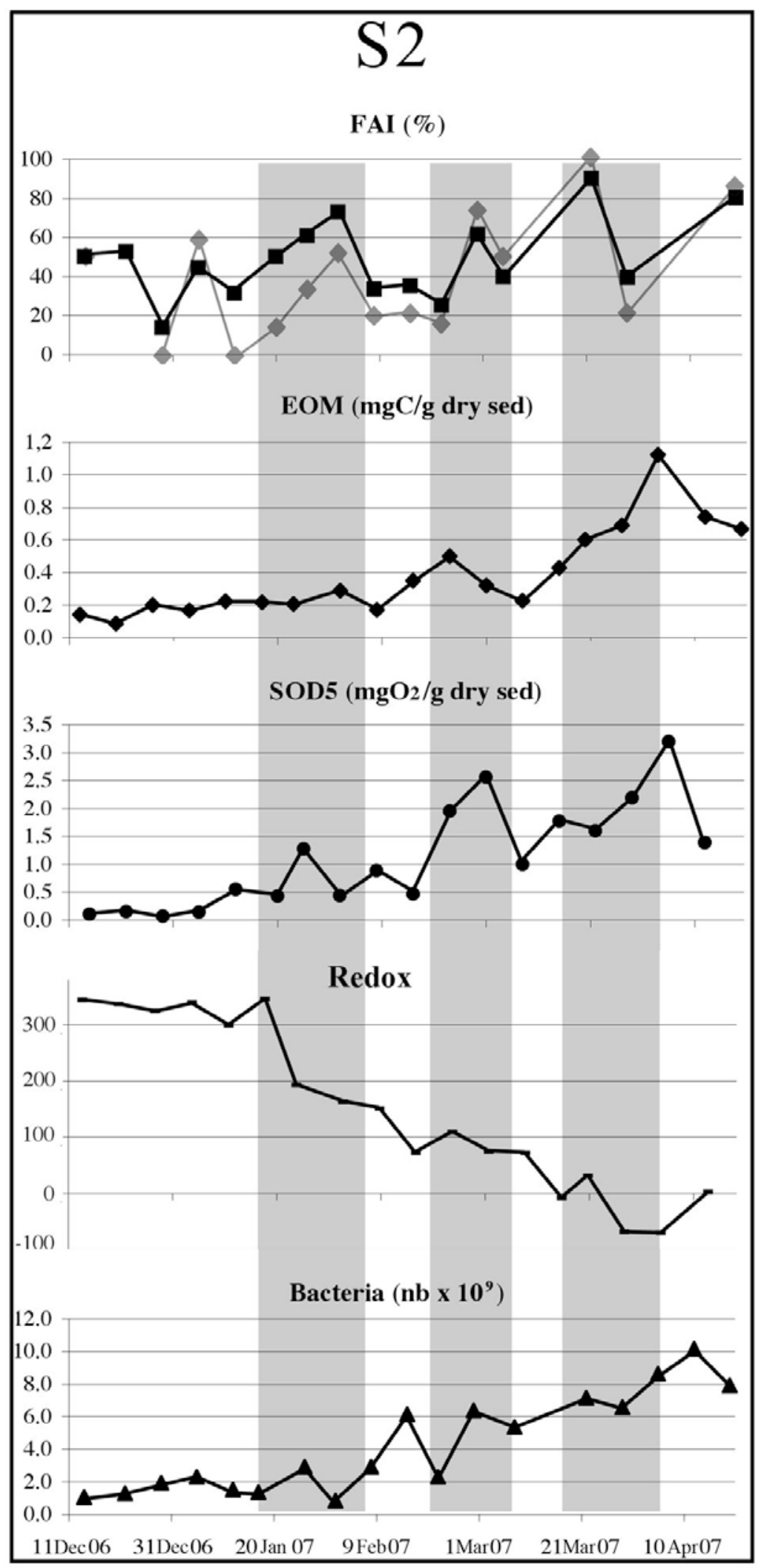

Figure 7: Changes in physico-chemical parameters and density of bacteria with time, compared with changes in FAI at station S2; shadows indicate the main peaks of FAI values, the gray curve is for living assemblages and the black one for total assemblages. 


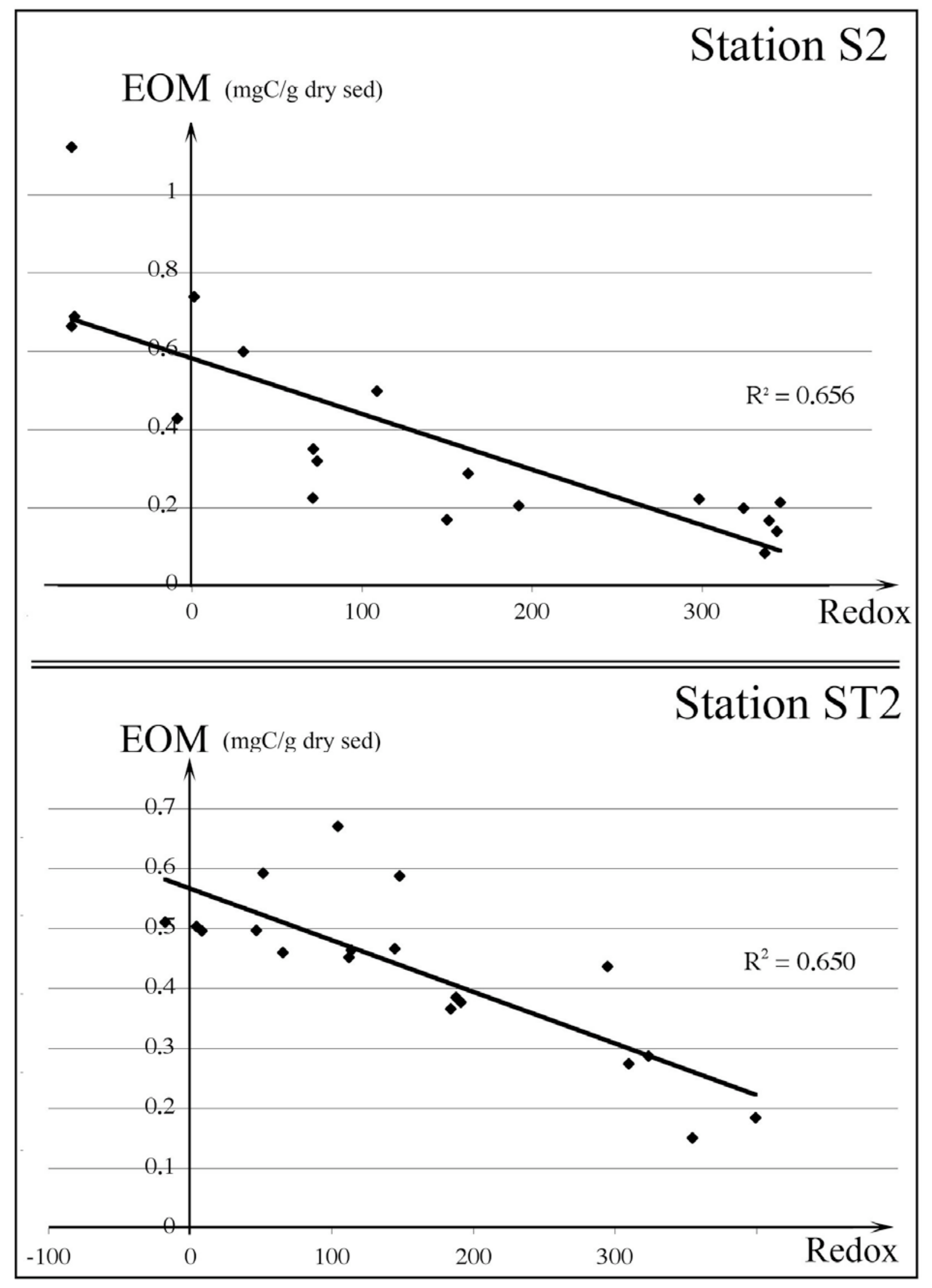

Figure 8: Relationships between EOM and redox at stations S2 and ST2. 


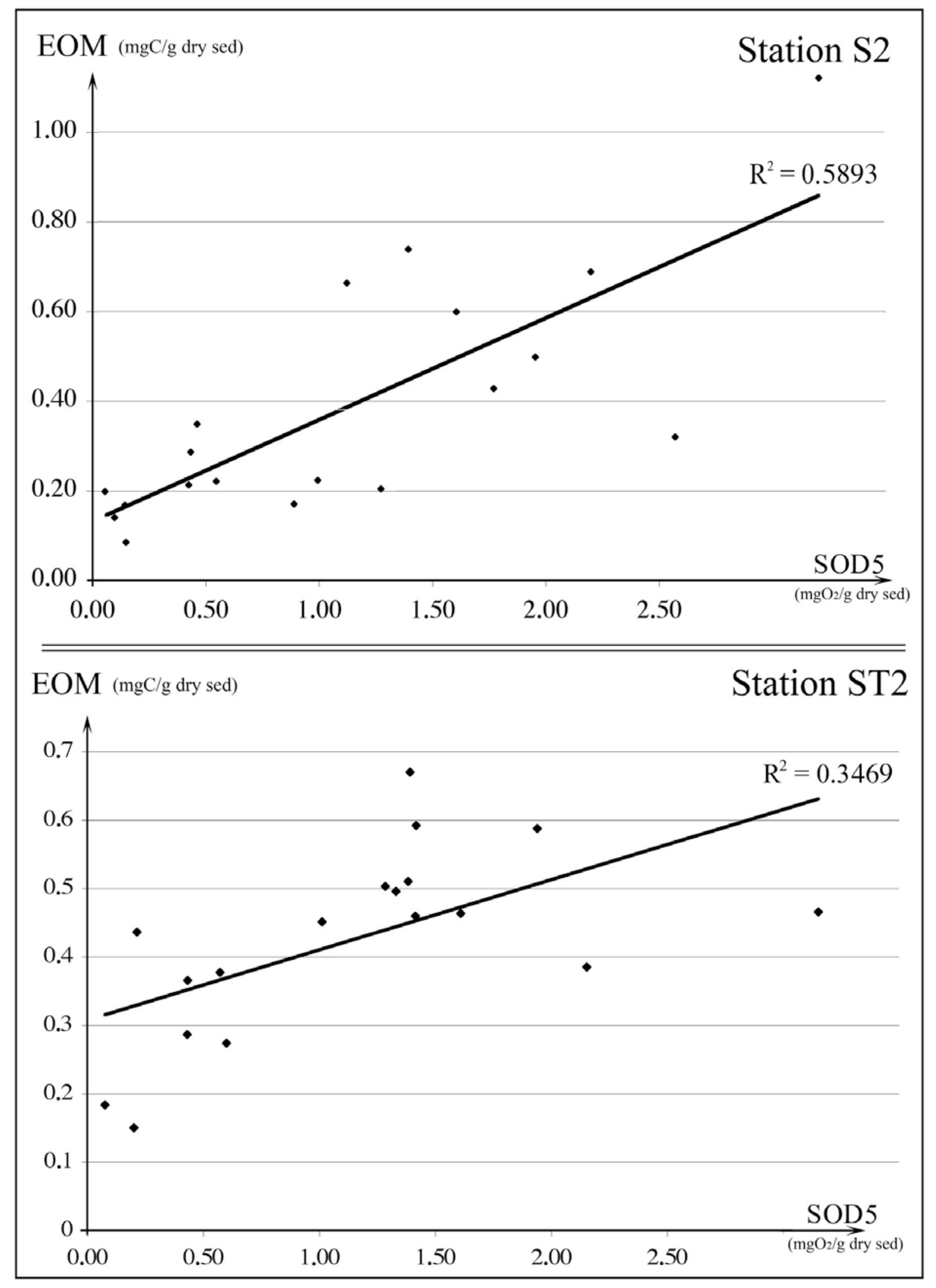

Figure 9: Relationships between EOM and SOD5 at stations S2 and ST2. 


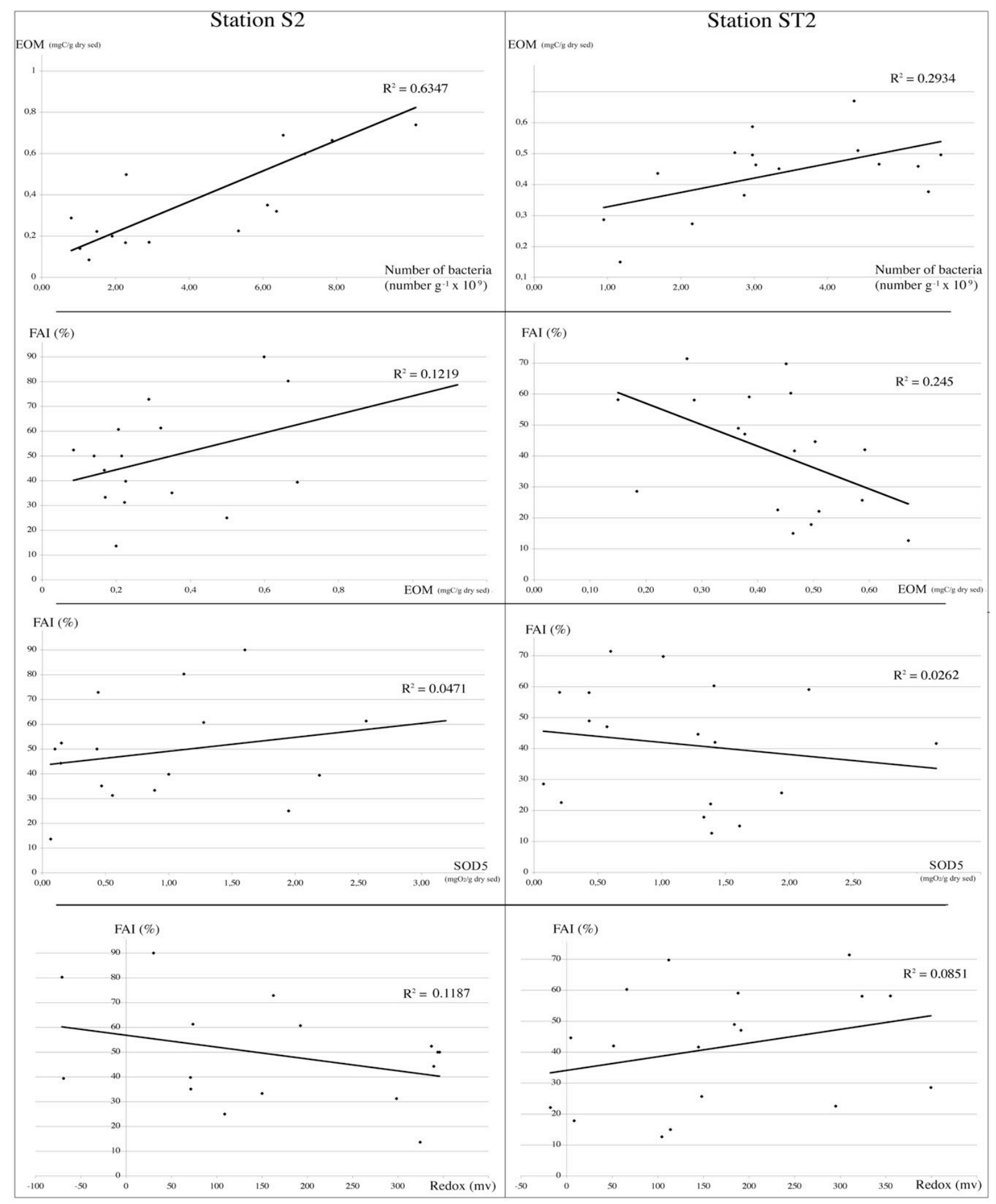

Figure 10: Relationships between the number of bacteria and EOM, and between FAI and EOM, SOD5 and Redox at stations S2 and ST2 
Table 1 - Average values of physico-chemical parameters and bacteria density. Heavy metals have been measured only once in 2007 , in all the ponds except SV.

\begin{tabular}{|c|c|c|c|c|c|c|c|c|c|c|c|c|c|c|c|c|}
\hline 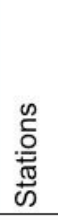 & & 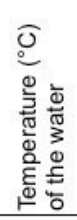 & 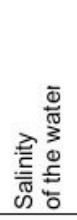 & 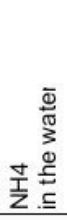 & 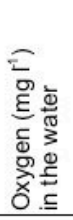 & 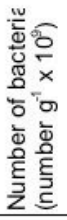 & 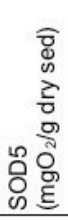 & 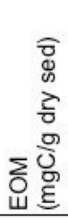 & 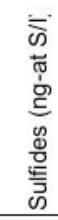 & 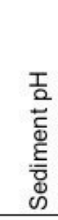 & 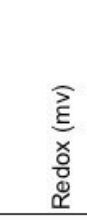 & $\begin{array}{l}\stackrel{\varrho}{\varrho} \\
\stackrel{0}{\Sigma}\end{array}$ & $\begin{array}{l}\widehat{E} \\
\text { 을 } \\
\text { J }\end{array}$ & $\frac{\mathfrak{g}}{\bar{z}}$ & $\begin{array}{l}\widehat{\varepsilon} \\
\text { 을 } \\
\hat{N}\end{array}$ & $\begin{array}{l}\stackrel{\varrho}{2} \\
\sum\end{array}$ \\
\hline \multirow{2}{*}{ SF1 } & Average & 25,32 & 34,84 & 2,31 & 5,88 & 4,17 & 9,08 & 2,33 & 0,05 & 7,66 & 17,68 & 5,79 & 24,00 & 0,05 & 86,00 & 0,08 \\
\hline & Stand Dev & 2,69 & 1,80 & 3,06 & 1,19 & 1,25 & 2,96 & 0,86 & 0,03 & 0,12 & 46,12 & 0,62 & & & & \\
\hline \multirow{2}{*}{$\mathrm{SF} 2$} & Average & 25,37 & 34,84 & 2,25 & 6,85 & 4,85 & 5,15 & 1,33 & 0,07 & 7,83 & 111,77 & 6,08 & & & & \\
\hline & Stand Dev & 2,53 & 1,80 & 2,29 & 0,87 & 2,22 & 2,21 & 0,31 & 0,04 & 0,14 & 56,62 & 1,04 & & & & \\
\hline \multirow{2}{*}{ SVA } & Average & 25,55 & 32,83 & 1,48 & 6,94 & 4,41 & 1,94 & 0,77 & 0,03 & 7,98 & 134,45 & 4,04 & & & & \\
\hline & Stand Dev & 3,26 & 1,61 & 1,74 & 0,94 & 1,18 & 0,96 & 0,20 & 0,04 & 0,11 & 25,65 & 0,51 & & & & \\
\hline \multirow{2}{*}{ SVB } & Average & 25,81 & 32,83 & 2,57 & 7,13 & 4,54 & 5,43 & 1,77 & 0,07 & 7,87 & 91,62 & 5,13 & & & & \\
\hline & Stand Dev & 3,18 & 1,61 & 2,71 & 1,08 & 1,41 & 2,13 & 0,52 & 0,03 & 0,12 & 38,04 & 0,73 & & & & \\
\hline \multirow{2}{*}{ S1 } & Average & 26,39 & 38,10 & 0,54 & 4,55 & 4,30 & 1,40 & 0,44 & 0,01 & 7,63 & 132,29 & 3,56 & 42,00 & 0,04 & 77,00 & 0,04 \\
\hline & Stand Dev & 1.67 & 1,29 & 0,86 & 1,16 & 1,30 & 0,90 & 0,26 & 0,02 & 0,22 & 112,02 & & & & & \\
\hline \multirow{2}{*}{$\mathrm{S} 2$} & Average & 26,45 & 38,74 & 0,13 & 4,84 & 4,24 & 1,12 & 0,39 & 0,01 & 7,69 & 138,51 & & & & & \\
\hline & Stand Dev & 1,66 & 1,55 & 0,18 & 1,35 & 3,01 & 0,91 & 0,27 & 0,02 & 0,44 & 153,82 & & & & & \\
\hline \multirow{2}{*}{ ST1 } & Average & 26,92 & 38,42 & 0,56 & 4,54 & 3,04 & 1,33 & 0,51 & 0,04 & 6,95 & 202,29 & 7,30 & 23,00 & 0,04 & 344,00 & 0,05 \\
\hline & Stand Dev & 1,63 & 1,35 & 1,64 & 1.07 & 1,35 & 0,75 & 0,22 & 0,06 & 0,41 & 125,06 & & & & & \\
\hline \multirow{2}{*}{ ST2 } & Average & 26,93 & 38,62 & 0,73 & 4,69 & 3,35 & 1,14 & 0,43 & 0,02 & 7,18 & 159,43 & & & & & \\
\hline & Stand Dev & 1.64 & 1,37 & 1,62 & 1,16 & 1,46 & 0,77 & 0,13 & 0,02 & 0,47 & 125,91 & & & & & \\
\hline \multirow{2}{*}{ TV1 } & Average & 27,02 & 38,97 & 0,54 & 4,32 & 2,64 & 1,03 & 0,61 & 0,01 & 7,27 & 196,25 & 5,72 & 46,00 & 0,06 & 99,00 & 0,15 \\
\hline & Stand Dev & 1,67 & 1,89 & 1,27 & 1,06 & 1,14 & 0,65 & 0,18 & 0,02 & 0,19 & 120,45 & & & & & \\
\hline \multirow{2}{*}{ TV2 } & Average & 26,88 & 38,56 & 0,08 & 4,42 & 3,10 & 1,40 & 0,66 & 0,02 & 6,93 & 171,31 & & & & & \\
\hline & Stand Dev & 1,64 & 1,43 & 0,15 & 1,08 & 1,42 & 0,85 & 0,21 & 0,03 & 0,29 & 99,15 & & & & & \\
\hline
\end{tabular}


Table 2 - Main foraminiferal data.
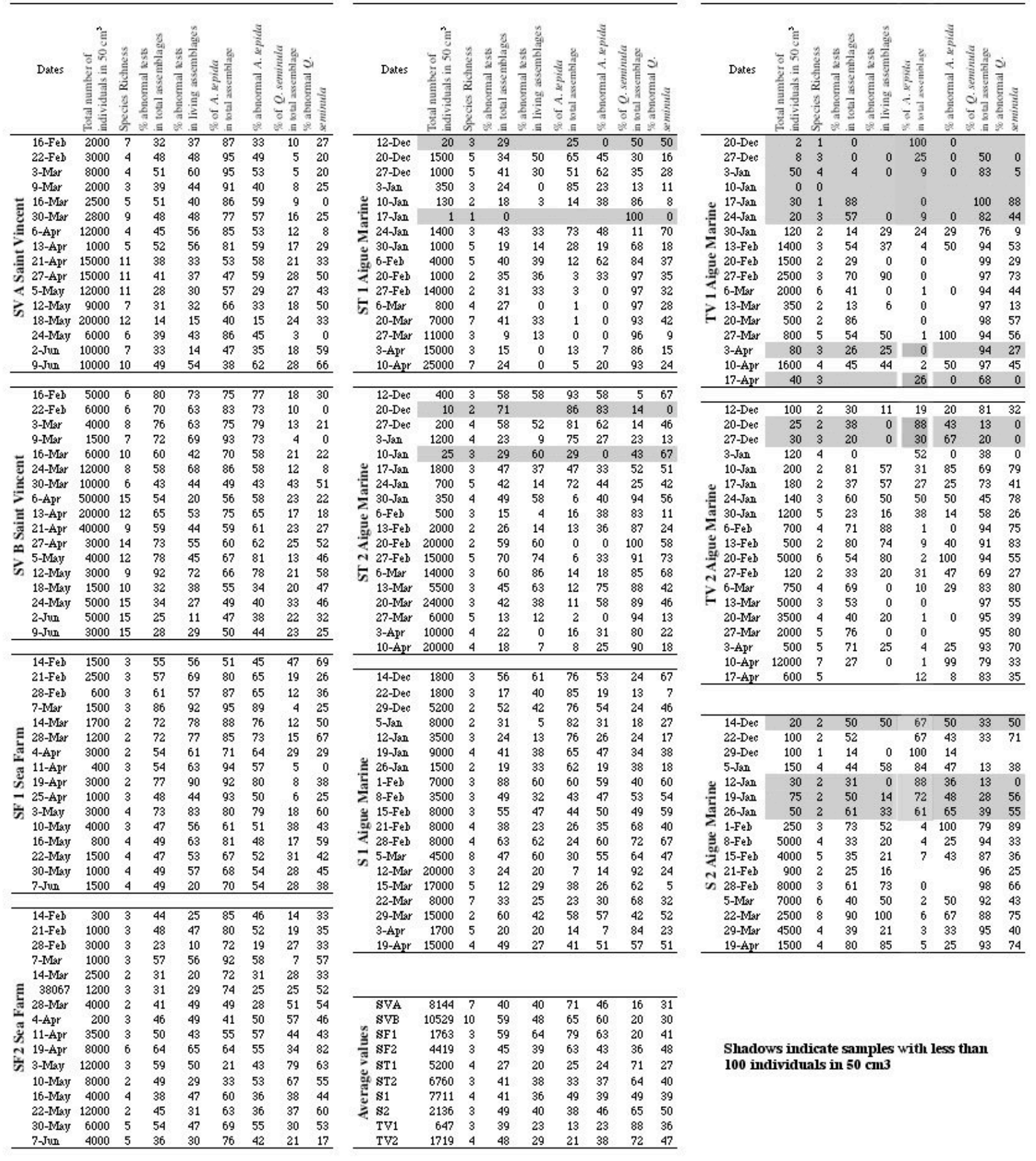

Shadows indicate samples with less than

100 individuals in $50 \mathrm{~cm} 3$ 
Table 3 - Correlation matrix (Pearson correlation coefficients) for the physico-chemical parameters, the abundance of bacteria and the Foraminiferal Abnormality index FAI.

\begin{tabular}{|c|c|c|c|c|c|c|c|c|c|c|c|c|c|}
\hline 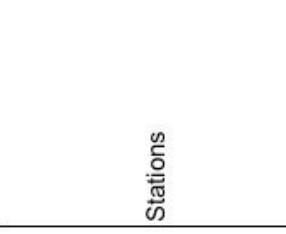 & 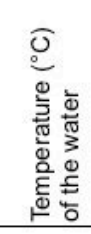 & 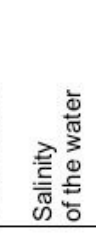 & 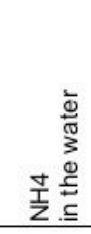 & 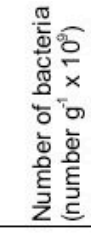 & 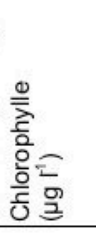 & 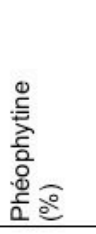 & 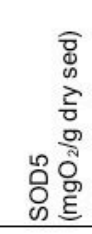 & 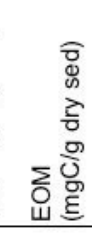 & 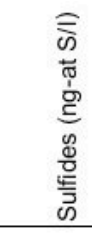 & 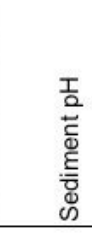 & 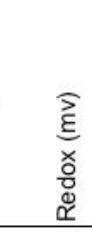 & 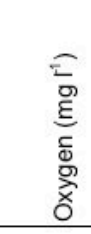 & $\frac{\grave{0}}{\stackrel{\mathbb{\alpha}}{4}}$ \\
\hline SF1 & 25,32 & 34,84 & 2,31 & 4,17 & 39,59 & 38,42 & 9,08 & 2,33 & 0,05 & 7,66 & 17,68 & 5,88 & 67,00 \\
\hline $\mathrm{SF} 2$ & 25,37 & 34,84 & 2,25 & 4,85 & 52,70 & 32,83 & 5,15 & 1,33 & 0,07 & 7,83 & 111,77 & 6,85 & 41,00 \\
\hline SVA & 25,55 & 32,83 & 1,48 & 4,41 & 18,16 & 15,10 & 1,94 & 0,77 & 0,03 & 7,98 & 134,45 & 6,94 & 40,00 \\
\hline SVB & 25,81 & 32,83 & 2,57 & 4,54 & 25,64 & 19,29 & 5,43 & 1,77 & 0,07 & 7,87 & 91,62 & 7,13 & 52,00 \\
\hline S1 & 26,39 & 38,10 & 0,54 & 4,30 & 9,49 & 29,06 & 1,40 & 0,44 & 0,01 & 7,63 & 132,29 & 4,55 & 41,00 \\
\hline S2 & 26,45 & 38,74 & 0,13 & 4,24 & 9,25 & 41,04 & 1,12 & 0,39 & 0,01 & 7,69 & 138,51 & 4,84 & 49,00 \\
\hline ST1 & 26,92 & 38,42 & 0,56 & 3,04 & 8,38 & 32,99 & 1,33 & 0,51 & 0,04 & 6,95 & 202,29 & 4,54 & 29,00 \\
\hline ST2 & 26,93 & 38,62 & 0,73 & 3,35 & 7,97 & 32,90 & 1,14 & 0,43 & 0,02 & 7,18 & 159,43 & 4,69 & 40,00 \\
\hline TV1 & 27,02 & 38,97 & 0,54 & 2,64 & 8,72 & 33,67 & 1.03 & 0,61 & 0,01 & 7,27 & 196,25 & 4,32 & 45,00 \\
\hline TV2 & 26,88 & 38,56 & 0,08 & 3,10 & 10,22 & 32,86 & 1,40 & 0,66 & 0,02 & 6,93 & 171,31 & 4,42 & 50,00 \\
\hline Temperature $\left({ }^{\circ} \mathrm{C}\right.$ ) & 1 & & & & & & & & & & & & \\
\hline Salinity & 0,8715 & 1 & & & & & & & & & & & \\
\hline $\mathrm{NH} 4$ & $-0,851$ & $-0,878$ & 1 & & & & & & & & & & \\
\hline Bacteria $\left(\mathrm{n} \times 10^{\exists}\right)$ & $-0,855$ & $-0,711$ & 0,6477 & 1 & & & & & & & & & \\
\hline Chlorophylle ( $\left.\left.\mu \mathrm{g}\right|^{-1}\right)$ & $-0,848$ & $-0,657$ & 0,8399 & 0,6503 & 1 & & & & & & & & \\
\hline Phéophytine (\%) & 0,3112 & 0,6801 & $-0,381$ & $-0,31$ & $-0,014$ & 1 & & & & & & & \\
\hline $\mathrm{SOD} 5\left(\mathrm{mgO}_{2} / \mathrm{g}\right.$ dry sed $)$ & $-0,787$ & $-0,648$ & 0,8581 & 0,5144 & 0,8319 & 0,0329 & 1 & & & & & & \\
\hline EOM (mgC/g dry sed) & $-0,756$ & $-0,701$ & 0,8784 & 0,4583 & 0,7841 & $-0,081$ & 0,981 & 1 & & & & & \\
\hline Sulfides (ng-at S/l) & $-0,744$ & $-0,788$ & 0,9005 & 0,5693 & 0,8271 & $-0,29$ & 0,7704 & 0,7873 & 1 & & & & \\
\hline Sediment $\mathrm{pH}$ & $-0,837$ & $-0,766$ & 0,6556 & 0,8938 & 0,5525 & $-0,429$ & 0,4608 & 0,4502 & 0,4648 & 1 & & & \\
\hline Redox (mv) & 0,8364 & 0,6483 & $-0,759$ & $-0,701$ & $-0,711$ & 0,0147 & $-0,905$ & $-0,863$ & $-0,578$ & $-0,65$ & 1 & & \\
\hline Oxygen (mg l-1) & $-0,876$ & $-0,967$ & 0,88 & 0,777 & 0,7296 & $-0,604$ & 0,6127 & 0,6487 & 0,8306 & 0,7998 & $-0,606$ & 1 & \\
\hline $\mathrm{FAl}(\%)$ & $-0,437$ & $-0,288$ & 0,3972 & 0,2411 & 0,3873 & 0,2358 & 0,7062 & 0,7226 & 0,2148 & 0,2948 & $-0,772$ & 0,2158 & 1 \\
\hline
\end{tabular}




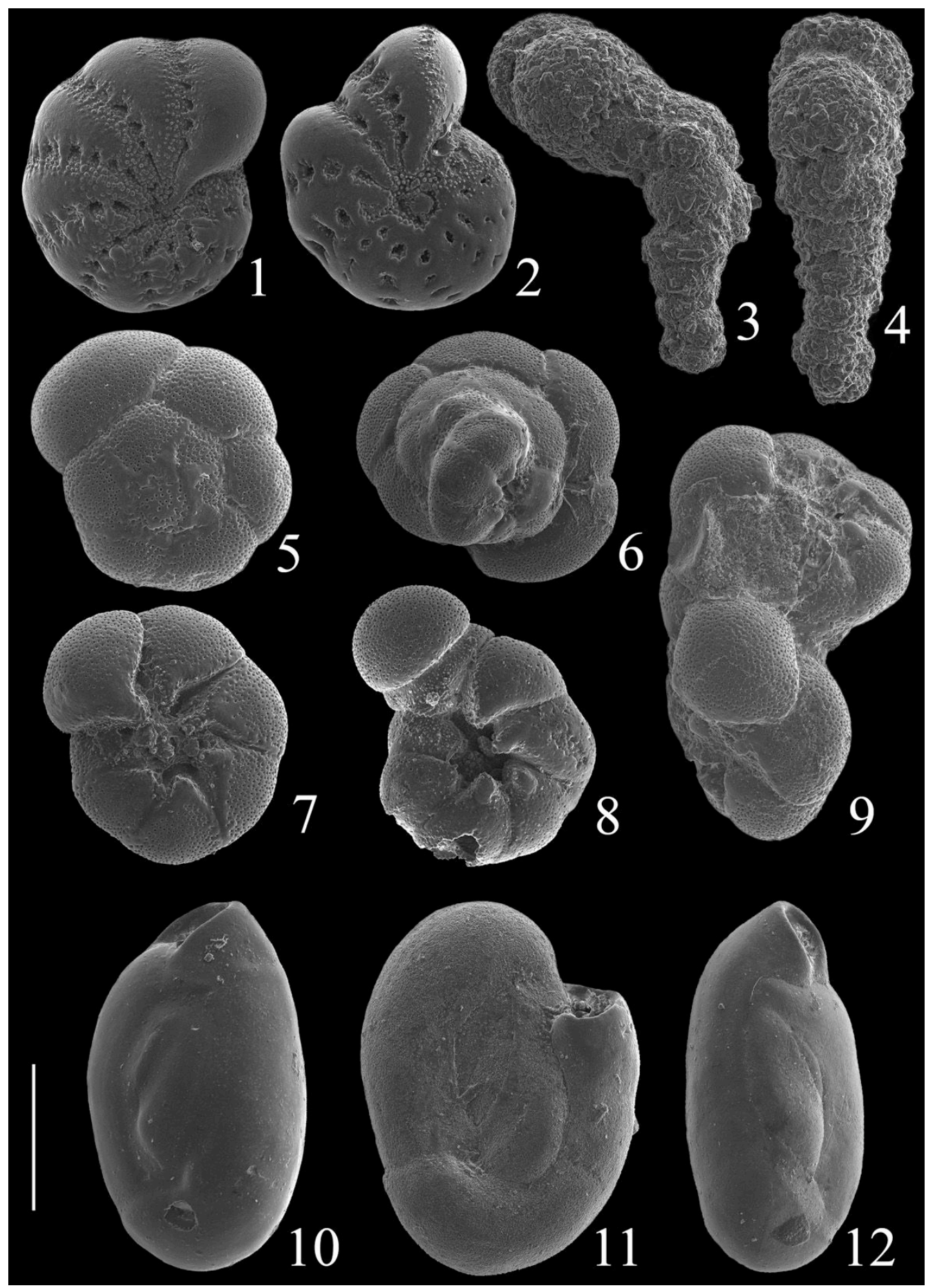

Plate 1

fig. 1: Elphidium excavatum, normal test; fig. 2: Elphidium excavatum, abnormal test; fig. 3: Caronia exilis, abnormal test; fig. 4: Caronia exilis, normal test; fig. 5: Ammonia tepida, spiral side, normal test; fig. 6: Ammonia tepida, spiral side, abnormal test; fig. 7: Ammonia tepida, umbilical side, normal test; fig. 8: Ammonia tepida, umbilical side, abnormal test; fig. 9: Ammonia tepida, complex abnormal test; fig. 10:

Quinqueloculina seminula, normal test; fig. 11: Quinqueloculina seminulum, abnormal test with the last chambers making less than half a whorl; fig. 12: Quinqueloculina seminulum, abnormal test with the last chamber making more than half a whorl. Scale bar $=100 \mu \mathrm{m}$ 